\title{
Global carbon budget 2013
}

C. Le Quéré ${ }^{1}$, G. P. Peters ${ }^{2}$, R. J. Andres ${ }^{3}$, R. M. Andrew ${ }^{2}$, T. A. Boden ${ }^{3}$, P. Ciais ${ }^{4}$, P. Friedlingstein ${ }^{5}$,

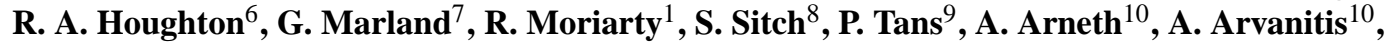
D. C. E. Bakker ${ }^{11}$, L. Bopp ${ }^{4}$, J. G. Canadell ${ }^{12}$, L. P. Chini ${ }^{13}$, S. C. Doney ${ }^{14}$, A. Harper ${ }^{15}$, I. Harris ${ }^{16}$, J. I. House ${ }^{17}$, A. K. Jain ${ }^{18}$, S. D. Jones ${ }^{1}$, E. Kato ${ }^{19}$, R. F. Keeling ${ }^{20}$, K. Klein Goldewijk ${ }^{21}$, A. Körtzinger ${ }^{22}$, C. Koven ${ }^{23}$, N. Lefèvre ${ }^{24}$, F. Maignan ${ }^{4}$, A. Omar ${ }^{25,26}$, T. Ono ${ }^{27}$, G.-H. Park ${ }^{28}$, B. Pfeil ${ }^{26,29}$, B. Poulter ${ }^{30}$, M. R. Raupach ${ }^{12, *}$, P. Regnier ${ }^{31}$, C. Rödenbeck ${ }^{32}$, S. Saito ${ }^{33}$, J. Schwinger ${ }^{26,29}$, J. Segschneider ${ }^{34}$, B. D. Stocker ${ }^{35}$, T. Takahashi ${ }^{36}$, B. Tilbrook ${ }^{37}$, S. van Heuven ${ }^{38}$, N. Viovy ${ }^{4}$, R. Wanninkhof ${ }^{40}$, A. Wiltshire ${ }^{39}$, and S. Zaehle ${ }^{32}$

${ }^{1}$ Tyndall Centre for Climate Change Research, University of East Anglia, Norwich Research Park, Norwich NR4 7TJ, UK

${ }^{2}$ Center for International Climate and Environmental Research - Oslo (CICERO), Norway

${ }^{3}$ Carbon Dioxide Information Analysis Center (CDIAC), Oak Ridge National Laboratory, Oak Ridge, Tennessee, USA

${ }^{4}$ Laboratoire des Sciences du Climat et de l'Environnement, CEA-CNRS-UVSQ, CE Orme des Merisiers, 91191 Gif sur Yvette CEDEX, France

${ }^{5}$ College of Engineering, Mathematics and Physical Sciences, University of Exeter, Exeter, EX4 4QF, UK

${ }^{6}$ Woods Hole Research Centre (WHRC), Falmouth, Massachusetts 02540, USA

${ }^{7}$ Research Institute for Environment, Energy, and Economics, Appalachian State University, Boone, North Carolina 28608, USA

${ }^{8}$ College of Life and Environmental Sciences University of Exeter, Exeter EX4 4RJ, UK

${ }^{9}$ National Oceanic \& Atmosphere Administration, Earth System Research Laboratory (NOAA/ESRL), Boulder, Colorado 80305, USA

${ }^{10}$ Karlsruhe Institute of Technology, Institute of Meteorology and Climate Research/Atmospheric Environmental Research, 82467 Garmisch-Partenkirchen, Germany

${ }^{11}$ Centre for Ocean and Atmospheric Sciences, School of Environmental Sciences, University of East Anglia, Norwich Research Park, Norwich, NR4 7TJ, UK

${ }^{12}$ Global Carbon Project, CSIRO Marine and Atmospheric Research, GPO Box 3023, Canberra, ACT 2601, Australia

${ }^{13}$ Department of Geographical Sciences, University of Maryland, College Park, Maryland 20742, USA

${ }^{14}$ Woods Hole Oceanographic Institution (WHOI), Woods Hole, Massachusetts 02543, USA

${ }^{15}$ College of Engineering, Mathematics and Physical Sciences, University of Exeter, UK

${ }^{16}$ Climatic Research Unit, University of East Anglia, Norwich Research Park, Norwich, NR4 7TJ, UK

${ }^{17}$ Cabot Institute, Dept of Geography, University of Bristol, Bristol BS8 1TH, UK

${ }^{18}$ Department of Atmospheric Sciences, University of Illinois, Urbana, Illinois 61821, USA

${ }^{19}$ Center for Global Environmental Research (CGER), National Institute for Environmental Studies (NIES), 16-2 Onogawa, Tsukuba, Ibaraki 305-8506, Japan

${ }^{20}$ University of California, San Diego, Scripps Institution of Oceanography, La Jolla, California 92093-0244, USA

${ }^{21}$ PBL Netherlands Environmental Assessment Agency, The Hague/Bilthoven and Utrecht University, Utrecht, the Netherlands

${ }^{22}$ GEOMAR Helmholtz Centre for Ocean Research, Wischhofstr. 1-3, 24148 Kiel, Germany

${ }^{23}$ Earth Sciences Division, Lawrence Berkeley National Lab, 1 Cyclotron Road, Berkeley, California 94720, 
${ }^{24}$ Sorbonne Universités (UPMC, Univ Paris 06)-CNRS-IRD-MNHN, LOCEAN Laboratory, 4 place Jussieu, 75005, Paris, France

${ }^{25}$ Uni Climate, Uni Research AS, Allégaten 55, 5007 Bergen, Norway

${ }^{26}$ Bjerknes Centre for Climate Research, Allégaten 55, 5007 Bergen, Norway

${ }^{27}$ Fisheries Research Agency, 2-3-3 Minato Mirai, Nishi-ku, Yokohama, Kanagawa 220-6115, Japan

${ }^{28}$ East Sea Research Institute, Korea Institute of Ocean Science \& Technology (KIOST), Uljin, 767-813, South Korea

${ }^{29}$ Geophysical Institute, University of Bergen, Bergen, Norway

${ }^{30}$ Department of Ecology, Montana State University, Bozeman, Montana 59717, USA

${ }^{31}$ Department of Earth \& Environmental Sciences, CP160/02, Université Libre de Bruxelles, 1050 Brussels, Belgium

${ }^{32}$ Max-Planck-Institut für Biogeochemie, P.O. Box 600164, Hans-Knöll-Str. 10, 07745 Jena, Germany

${ }^{33}$ Marine Division, Global Environment and Marine Department, Japan Meteorological Agency, 1-3-4

Otemachi, Chiyoda-ku, Tokyo 100-8122, Japan

${ }^{34}$ Max Planck Institute for Meteorology, Bundesstr. 53, 20146 Hamburg, Germany

${ }^{35}$ Climate and Environmental Physics, and Oeschger Centre for Climate Change Research, University of Bern, Switzerland

${ }^{36}$ Columbia Univ, Lamont-Doherty Earth Observatory, Palisades, NY 10964, USA

${ }^{37}$ CSIRO Marine and Atmospheric Research and Antarctic Climate and Ecosystems Co-operative Research Centre, Hobart, Australia

${ }^{38}$ Centre for Isotope Research, University of Groningen, Groningen, the Netherlands

${ }^{39}$ NOAA/AOML, Miami, Florida 33149, USA

${ }^{40}$ Met Office Hadley Centre, FitzRoy Road, Exeter EX1 3PB, UK

*now at: Climate Change Institute, Australian National Universtiy, Canberra, ACT, Australia

Correspondence to: C. Le Quéré (c.lequere@uea.ac.uk)

Received: 7 November 2013 - Published in Earth Syst. Sci. Data Discuss.: 19 November 2013

Revised: 4 April 2014 - Accepted: 11 April 2014 - Published: 17 June 2014

Abstract. Accurate assessment of anthropogenic carbon dioxide $\left(\mathrm{CO}_{2}\right)$ emissions and their redistribution among the atmosphere, ocean, and terrestrial biosphere is important to better understand the global carbon cycle, support the development of climate policies, and project future climate change. Here we describe data sets and a methodology to quantify all major components of the global carbon budget, including their uncertainties, based on the combination of a range of data, algorithms, statistics and model estimates and their interpretation by a broad scientific community. We discuss changes compared to previous estimates, consistency within and among components, alongside methodology and data limitations. $\mathrm{CO}_{2}$ emissions from fossil-fuel combustion and cement production $\left(E_{\mathrm{FF}}\right)$ are based on energy statistics, while emissions from land-use change $\left(E_{\mathrm{LUC}}\right)$, mainly deforestation, are based on combined evidence from land-cover change data, fire activity associated with deforestation, and models. The global atmospheric $\mathrm{CO}_{2}$ concentration is measured directly and its rate of growth $\left(G_{\text {ATM }}\right)$ is computed from the annual changes in concentration. The mean ocean $\mathrm{CO}_{2}$ sink $\left(S_{\text {OCEAN }}\right)$ is based on observations from the 1990s, while the annual anomalies and trends are estimated with ocean models. The variability in $S_{\text {OCEAN }}$ is evaluated for the first time in this budget with data products based on surveys of ocean $\mathrm{CO}_{2}$ measurements. The global residual terrestrial $\mathrm{CO}_{2} \operatorname{sink}\left(S_{\mathrm{LAND}}\right)$ is estimated by the difference of the other terms of the global carbon budget and compared to results of independent dynamic global vegetation models forced by observed climate, $\mathrm{CO}_{2}$ and land cover change (some including nitrogen-carbon interactions). All uncertainties are reported as $\pm 1 \sigma$, reflecting the current capacity to characterise the annual estimates of each component of the global carbon budget. For the last decade available (2003-2012), $E_{\mathrm{FF}}$ was $8.6 \pm 0.4 \mathrm{GtC} \mathrm{yr}^{-1}$, $E_{\text {LUC }} 0.9 \pm 0.5 \mathrm{GtC} \mathrm{yr}^{-1}, G_{\text {ATM }} 4.3 \pm 0.1 \mathrm{GtC} \mathrm{yr}^{-1}, S_{\text {OCEAN }} 2.5 \pm 0.5 \mathrm{GtC} \mathrm{yr}^{-1}$, and $S_{\text {LAND }} 2.8 \pm 0.8 \mathrm{GtC} \mathrm{yr}^{-1}$. For year 2012 alone, $E_{\mathrm{FF}}$ grew to $9.7 \pm 0.5 \mathrm{GtC} \mathrm{yr}^{-1}, 2.2 \%$ above 2011, reflecting a continued growing trend in these emissions, $G_{\mathrm{ATM}}$ was $5.1 \pm 0.2 \mathrm{GtC} \mathrm{yr}^{-1}, S_{\mathrm{OCEAN}}$ was $2.9 \pm 0.5 \mathrm{GtC} \mathrm{yr}^{-1}$, and assuming an $E_{\mathrm{LUC}}$ of $1.0 \pm 0.5 \mathrm{GtC} \mathrm{yr}^{-1}$ (based on the 2001-2010 average), $S_{\text {LAND }}$ was $2.7 \pm 0.9 \mathrm{GtC} \mathrm{yr}^{-1}$. $G_{\text {ATM }}$ was high in 2012 compared to the 2003-2012 average, almost entirely reflecting the high $E_{\mathrm{FF}}$. The global atmospheric $\mathrm{CO}_{2}$ concentration reached $392.52 \pm 0.10 \mathrm{ppm}$ averaged over 2012. We estimate that $E_{\mathrm{FF}}$ will increase by $2.1 \%$ (1.1$3.1 \%$ ) to $9.9 \pm 0.5 \mathrm{GtC}$ in $2013,61 \%$ above emissions in 1990 , based on projections of world gross domestic product and recent changes in the carbon intensity of the economy. With this projection, cumulative emissions of 
$\mathrm{CO}_{2}$ will reach about $535 \pm 55 \mathrm{GtC}$ for $1870-2013$, about $70 \%$ from $E_{\mathrm{FF}}(390 \pm 20 \mathrm{GtC})$ and $30 \%$ from $E_{\mathrm{LUC}}$ $(145 \pm 50 \mathrm{GtC})$.

This paper also documents any changes in the methods and data sets used in this new carbon budget from previous budgets (Le Quéré et al., 2013). All observations presented here can be downloaded from the Carbon Dioxide Information Analysis Center (doi:10.3334/CDIAC/GCP_2013_V2.3).

\section{Introduction}

The concentration of carbon dioxide $\left(\mathrm{CO}_{2}\right)$ in the atmosphere has increased from approximately 277 parts per million (ppm) in 1750 (Joos and Spahni, 2008), the beginning of the Industrial Era, to 392.52 in 2012 (Dlugokencky and Tans, 2013). Daily averages went above $400 \mathrm{ppm}$ for the first time at Mauna Loa station in May 2013 (Scripps, 2013). This station holds the longest running record of direct measurements of atmospheric $\mathrm{CO}_{2}$ concentration (Tans and Keeling, 2013). The atmospheric $\mathrm{CO}_{2}$ increase above preindustrial levels was initially, primarily, caused by the release of carbon to the atmosphere from deforestation and other land-use change activities (Ciais et al., 2013). Emissions from fossilfuel combustion started before the Industrial Era and became the dominant source of anthropogenic emissions to the atmosphere from around 1920 and continued to be the dominant source until present. Anthropogenic emissions occur on top of an active natural carbon cycle that circulates carbon between the atmosphere, ocean, and terrestrial biosphere reservoirs on timescales from days to millennia, while exchanges with geologic reservoirs have even longer timescales (Archer et al., 2009).

The global carbon budget presented here refers to the mean, variations, and trends in the perturbation of $\mathrm{CO}_{2}$ in the atmosphere, referenced to the beginning of the Industrial Era. It quantifies the input of $\mathrm{CO}_{2}$ to the atmosphere by emissions from human activities, the growth of $\mathrm{CO}_{2}$ in the atmosphere, and the resulting changes in the storage of carbon in the land and ocean reservoirs in response to increasing atmospheric $\mathrm{CO}_{2}$ levels, climate change and climate variability, and other anthropogenic and natural changes. An understanding of this perturbation budget over time and the underlying variability and trends of the natural carbon cycle are necessary to understand the response of natural sinks to changes in climate, $\mathrm{CO}_{2}$ and land-use change drivers, and the permissible emissions for a given climate stabilisation target.

The components of the $\mathrm{CO}_{2}$ budget that are reported in this paper include separate estimates for (1) the $\mathrm{CO}_{2}$ emissions from fossil-fuel combustion and cement production $\left(E_{\mathrm{FF}}\right)$, (2) the $\mathrm{CO}_{2}$ emissions resulting from deliberate human activities on land leading to land-use change (LUC; $E_{\mathrm{LUC}}$ ), (3) the growth rate of $\mathrm{CO}_{2}$ in the atmosphere $\left(G_{\mathrm{ATM}}\right)$, and the uptake of $\mathrm{CO}_{2}$ by the "CO $\mathrm{CO}_{2}$ sinks" in (4) the ocean ( $\left.S_{\text {OCEAN }}\right)$ and (5) on land $\left(S_{\mathrm{LAND}}\right)$. The $\mathrm{CO}_{2}$ sinks as defined here include the response of the land and ocean to elevated $\mathrm{CO}_{2}$ and changes in climate and other environmental conditions. The global emissions and their partitioning among the atmosphere, ocean and land are in balance:

$E_{\mathrm{FF}}+E_{\mathrm{LUC}}=G_{\mathrm{ATM}}+S_{\mathrm{OCEAN}}+S_{\mathrm{LAND}}$.

$G_{\text {ATM }}$ is usually reported in ppm, which we convert to units of carbon mass using $1 \mathrm{ppm}=2.120 \mathrm{GtC}$ (Prather et al., 2012; Table 1). We also include a quantification of $E_{\mathrm{FF}}$ by country, both computed with territorial and consumptionbased accounting (see Methods).

Equation (1) partly omits two kinds of processes. The first is the net input of $\mathrm{CO}_{2}$ to the atmosphere from the chemical oxidation of reactive carbon-containing gases from sources other than fossil fuels (e.g. landfills, industrial processes, etc.), primarily methane $\left(\mathrm{CH}_{4}\right)$, carbon monoxide $(\mathrm{CO})$, and volatile organic compounds such as isoprene and terpene. The second is the anthropogenic perturbation to carbon cycling in terrestrial freshwaters, estuaries, and coastal areas, that modifies lateral fluxes from land ecosystems to the open ocean, the evasion $\mathrm{CO}_{2}$ flux from rivers, lakes and estuaries to the atmosphere, and the net air-sea anthropogenic $\mathrm{CO}_{2}$ flux of coastal areas (Regnier et al., 2013). These flows are omitted in the absence of annual information on the natural versus anthropogenic perturbation terms of these loops of the carbon cycle, and they are discussed in Sect. 2.6. The inclusion of these fluxes of anthropogenic $\mathrm{CO}_{2}$ would affect the estimates of, and partitioning between, $S_{\text {LAND }}$ and $S_{\text {OCEAN }}$ in Eq. (1) in complementary ways, but would not affect the other terms in Eq. (1).

The $\mathrm{CO}_{2}$ budget has been assessed by the Intergovernmental Panel on Climate Change (IPCC) in all assessment reports (Ciais et al., 2013; Denman et al., 2007; Prentice et al., 2001; Schimel et al., 1995; Watson et al., 1990), and by others (e.g. Ballantyne et al., 2012). These assessments included budget estimates for the decades of the 1980s, 1990s (Denman et al., 2007) and, most recently, the period 2002-2011 (Ciais et al., 2013). The IPCC methodology has been adapted and used by the Global Carbon Project (GCP, www.globalcarbonproject. org), which has coordinated a cooperative community effort for the annual publication of global carbon budgets up to year 2005 (Raupach et al., 2007; including fossil emissions only), year 2006 (Canadell et al., 2007), year 2007 (published online; GCP, 2007), year 2008 (Le Quéré et al., 2009), year 2009 (Friedlingstein et al., 2010), year 2010 (Peters et al., 2012b), and most recently, year 2011 (Le Quéré et al., 2013; Peters et al., 2013). Each of these papers updated previous 
Table 1. Factors used to convert carbon in various units (by convention, Unit $1=$ Unit $2 \cdot$ conversion).

\begin{tabular}{llrl}
\hline Unit 1 & Unit 2 & Conversion & Source \\
\hline GtC (gigatonnes of Carbon) & ppm (parts per million) & 2.120 & Prather et al. (2012) \\
GtC (gigatonnes of Carbon) & PgC (petagrammes of Carbon) & 1 & SI unit conversion \\
$\mathrm{GtCO}_{2}$ (gigatonnes of Carbon Dioxide) & $\mathrm{GtC}$ (gigatonnes of Carbon) & 3.664 & $44 / 12$ in mass equivalent \\
$\mathrm{GtC}$ (gigatonnes of Carbon) & $\mathrm{MtC}$ (megatonnes of Carbon) & 1000 & SI unit conversion \\
\hline
\end{tabular}

estimates with the latest available information for the entire time series. From 2008, these publications projected fossilfuel emissions for 1 additional year using the projected world gross domestic product and estimated improvements in the carbon intensity of the economy.

We adopt a range of \pm 1 standard deviation $(\sigma)$ to report the uncertainties in our estimates, representing a likelihood of $68 \%$ that the true value will be within the provided range if the errors have a Gaussian distribution. This choice reflects the difficulty of characterising the uncertainty in the $\mathrm{CO}_{2}$ fluxes between the atmosphere and the ocean and land reservoirs individually, particularly on an annual basis, as well as the difficulty of updating the $\mathrm{CO}_{2}$ emissions from LUC. A likelihood of $68 \%$ provides an indication of our current capability to quantify each term and its uncertainty given the available information. For comparison, the Fifth Assessment Report of the IPCC (AR5) generally reported a likelihood of $90 \%$ for large data sets whose uncertainty is well characterised, or for long time intervals less affected by year-to-year variability. Our $68 \%$ uncertainty value is near the $66 \%$ that the IPCC characterises as "likely" for values falling into the $\pm 1 \sigma$ interval. The uncertainties reported here combine statistical analysis of the underlying data and expert judgement of the likelihood of results lying outside this range. The limitations of current information are discussed in the paper.

All units are presented in gigatonnes of carbon $(\mathrm{GtC}$, $\left.10^{15} \mathrm{gC}\right)$, which is the same as petagrams of carbon $(\mathrm{PgC} ; \mathrm{Ta}-$ ble 1). Units of gigatonnes of $\mathrm{CO}_{2}$ (or billion tonnes of $\mathrm{CO}_{2}$ ) used in policy are equal to 3.664 multiplied by the value in units of GtC.

This paper provides a detailed description of the data sets and methodology used to compute the global carbon budget estimates for the preindustrial period (1750) to 2012 and in more detail for the period 1959 to 2012. We also provide decadal averages starting in 1960 including the last decade (2003-2012), results for the year 2012, and a projection of $E_{\mathrm{FF}}$ for year 2013 . Finally we provide the total or cumulative emissions from fossil fuels and land-use change since the year 1750, the preindustrial period, and since the year 1870 , the reference year for the cumulative carbon estimate used by the Fifth Assessment Report of the Intergovernmental Panel on Climate Change based on the availability of global temperature data (Stocker et al., 2013b). This paper will be updated every year using the format of "living data" in order to keep a record of budget versions and the changes in new data, revision of data, and changes in methodology that lead to changes in estimates of the carbon budget. Additional materials associated with the release of each new version will be posted at the Global Carbon Project (GCP) website (http://www.globalcarbonproject.org/carbonbudget). Data associated with this release are also available through the Global Carbon Atlas (http://www.globalcarbonatlas.org). With this approach, we aim to provide the highest transparency and traceability in the reporting of a set of key indicators and drivers of climate change.

\section{Methods}

Multiple organisations and research groups around the world generated the original measurements and data used to complete the global carbon budget. The effort presented here is thus mainly one of synthesis, where results from individual groups are collated, analysed and evaluated for consistency. We facilitate access to original data with the understanding that primary data sets will be referenced in future work (see Table 2 for "How to cite" the data sets). Descriptions of the measurements, models, and methodologies follow below and in-depth descriptions of each component are described elsewhere (e.g. Andres et al., 2012; Houghton et al., 2012).

This is the second revised version of the "global carbon budget". It is an update of Le Quéré et al. (2013), including data until year 2012 and a projection for fossil-fuel emissions for year 2013. The main changes from Le Quéré et al. (2013) are (1) we have introduced a new section (Sect. 2.6) that describes and quantifies the main missing processes; (2) we have introduced data products to assess the interannual variability in the ocean $\mathrm{CO}_{2}$ sink; (3) we have introduced a qualitative assessment of confidence level to characterise the annual estimates from each term based on the type, amount, quality and consistency of the evidence as defined by the IPCC (Stocker et al., 2013b); and (4) we have also updated the cumulative $\mathrm{CO}_{2}$ emissions. The main methodological differences between annual carbon budgets are summarised in Table 3. 
Table 2. How to cite the individual components of the global carbon budget presented here.

\begin{tabular}{ll}
\hline Component & Primary reference \\
\hline $\begin{array}{l}\text { Territorial fossil-fuel and cement emissions }\left(E_{\mathrm{FF}}\right) \\
\text { global, by fuel type, and by country }\end{array}$ & $\begin{array}{l}\text { Boden et al. (2013; CDIAC: http://cdiac.ornl.gov/ } \\
\text { trends/emis/meth_reg.html) }\end{array}$ \\
\hline $\begin{array}{l}\text { Consumption-based fossil-fuel and cement emissions } \\
\left(E_{\mathrm{FF}}\right) \text { by country (consumption) }\end{array}$ & $\begin{array}{l}\text { Peters et al. (2011b) updated as described in Le Quéré } \\
\text { et al. (this paper) }\end{array}$ \\
\hline Land-use change emissions $\left(E_{\mathrm{LUC}}\right)$ & Houghton et al. (2012) \\
\hline Atmospheric $\mathrm{CO}_{2}$ growth rate & $\begin{array}{l}\text { Dlugokencky and Tans }(2013 ; \text { NOAA/ESRL: www. } \\
\text { esrl.noaa.gov/gmd/ccgg/trends/) }\end{array}$ \\
\hline Ocean and land $\mathrm{CO}_{2}$ sinks $\left(S_{\mathrm{OCEAN}}\right.$ and $\left.S_{\mathrm{LAND}}\right)$ & $\begin{array}{l}\text { Le Quéré et al. (this paper) for } S_{\mathrm{OCEAN}} \text { and } S_{\mathrm{LAND}} \text { and } \\
\text { references in Table } 6 \text { for individual models. }\end{array}$ \\
\hline
\end{tabular}

\section{1 $\mathrm{CO}_{2}$ emissions from fossil-fuel combustion and cement production $\left(E_{\mathrm{FF}}\right)$}

\subsubsection{Fossil-fuel and cement emissions and their uncertainty}

The calculation of global and national $\mathrm{CO}_{2}$ emissions from fossil-fuel combustion, including gas flaring and cement production $\left(E_{\mathrm{FF}}\right)$, relies primarily on energy consumption data, specifically data on hydrocarbon fuels, collated and archived by several organisations (Andres et al., 2012). These include the Carbon Dioxide Information Analysis Center (CDIAC), the International Energy Agency (IEA), the United Nations (UN), the United States Department of Energy (DoE) Energy Information Administration (EIA), and more recently also the PBL Netherlands Environmental Assessment Agency. We use the emissions estimated by the CDIAC (Boden et al., 2013). The CDIAC emission estimates are the only ones that extend back in time to 1751 with consistent and welldocumented emissions from fossil-fuel combustion, cement production, and gas flaring for all countries, including their uncertainty (Andres et al., 1999, 2012); this makes the data set a unique resource for research of the carbon cycle during the fossil-fuel era. During the period 1959-2010, the emissions are based primarily on energy data provided by the UN Statistics Division (Table 4; UN, 2013a, b). For the most recent 2 years (2011 and 2012) when the UN statistics are not yet available, CDIAC generated preliminary estimates based on the BP annual energy review for extrapolation of emissions in 2011 and 2012 (BP, 2013). BP's sources for energy statistics overlap with those of the UN data, but are compiled more rapidly using about 70 countries covering about $96 \%$ of global emissions. We use the BP values only for the yearto-year rate of change, because the rates of change are less uncertain than the absolute values and to avoid discontinuities in the time series when linking the UN-based energy data (up to 2010) with the BP energy data (2011 and 2012). These preliminary estimates are replaced by the more complete CDIAC data based on UN statistics when they become available. Past experience shows that projections based on the BP rate of change provide reliable estimates for the two most recent years (see Sect. 3.2 and the Supplement from Peters et al., 2013).

When necessary, fuel masses/volumes are converted to fuel energy content using coefficients provided by the UN and then to $\mathrm{CO}_{2}$ emissions using conversion factors that take into account the relationship between carbon content and heat content of the different fuel types (coal, oil, gas, gas flaring) and the combustion efficiency (to account, for example, for soot left in the combustor or fuel otherwise lost or discharged without oxidation). Most data on energy consumption and fuel quality are available at the country level. In general, $\mathrm{CO}_{2}$ emissions for equivalent primary energy consumption are about $30 \%$ higher for coal compared to oil, and $70 \%$ higher for coal compared to natural gas (Marland et al., 2007). All estimated fossil-fuel emissions are based on the mass flows of carbon and assume that the fossil carbon emitted as $\mathrm{CO}$ or $\mathrm{CH}_{4}$ will soon be oxidised to $\mathrm{CO}_{2}$ in the atmosphere and can be accounted with $\mathrm{CO}_{2}$ emissions.

Emissions from cement production are based on cement data from the US Geological Survey (van Oss, 2013) up to year 2010, and from preliminary data for 2011 and 2012 where available (US Geological Survey, 2013). Some fraction of the $\mathrm{CaO}$ and $\mathrm{MgO}$ in cement is returned to the carbonate form during cement weathering but this is generally regarded to be small and is ignored here.

Emission estimates from gas flaring are calculated in a similar manner as those from solid, liquid, and gaseous fuels, and rely on the UN Energy Statistics to supply the amount of flared or vented fuel. For emission years 2011 and 2012, flaring is assumed constant from the emission year $2010 \mathrm{UN}$ based data. The basic data on gas flaring report atmospheric losses during petroleum production and processing that have large uncertainty and do not distinguish between gas that is flared as $\mathrm{CO}_{2}$ or vented as $\mathrm{CH}_{4}$. Fugitive emissions of $\mathrm{CH}_{4}$ from the so-called upstream sector (e.g. coal mining and natural gas distribution) are not included in the accounts of $\mathrm{CO}_{2}$ 
Table 3. Main methodological changes in the global carbon budget since first publication. Unless specified below, the methodology was identical to that described in the current paper. Furthermore, methodological changes introduced in one year are kept for the following years unless noted. Empty cells mean there were no methodological changes introduced that year.

\begin{tabular}{|c|c|c|c|c|c|c|c|c|}
\hline \multirow[t]{2}{*}{ Publication year $^{\mathrm{a}}$} & \multicolumn{3}{|c|}{ Fossil-fuel emissions } & \multirow[t]{2}{*}{ LUC emissions } & \multicolumn{3}{|c|}{ Reservoirs } & \multirow{2}{*}{$\begin{array}{l}\text { Uncertainty and } \\
\text { other changes }\end{array}$} \\
\hline & Global & $\begin{array}{l}\text { Country } \\
\text { (territorial) }\end{array}$ & $\begin{array}{l}\text { Country } \\
\text { (consumption) }\end{array}$ & & Atmosphere & Ocean & Land & \\
\hline $\begin{array}{l}2006 \\
\text { Raupach et al. (2007) }\end{array}$ & & Split in regions & & & & & & \\
\hline $\begin{array}{l}2007 \\
\text { Canadell et al. (2007) }\end{array}$ & & & & $\begin{array}{l}E_{\text {LUC }} \text { based } \\
\text { on FAO-FRA } \\
2005 ; \text { constant } \\
E_{\text {LUC }} \text { for } 2006\end{array}$ & $\begin{array}{l}\text { 1959-1979 } \\
\text { data from } \\
\text { Mauna Loa; } \\
\text { data after 1980 } \\
\text { from global } \\
\text { average }\end{array}$ & $\begin{array}{l}\text { Based on one } \\
\text { ocean model } \\
\text { tuned to repro- } \\
\text { duced observed } \\
\text { 1990s sink }\end{array}$ & & $\begin{array}{l} \pm 1 \sigma \text { provided for } \\
\text { all components }\end{array}$ \\
\hline $\begin{array}{l}2008 \\
\text { (online release) }\end{array}$ & & & & $\begin{array}{l}\text { Constant } E_{\text {LUC }} \\
\text { for } 2007\end{array}$ & & & & \\
\hline $\begin{array}{l}2009 \\
\text { Le Quéré et al. (2009) }\end{array}$ & & $\begin{array}{l}\text { Split between } \\
\text { Annex B and } \\
\text { non-Annex B }\end{array}$ & $\begin{array}{l}\text { Results from } \\
\text { an independent } \\
\text { study discussed }\end{array}$ & $\begin{array}{l}\text { Fire-based } \\
\text { emission } \\
\text { anomalies used } \\
\text { for 2006-2008 }\end{array}$ & & $\begin{array}{l}\text { Based on four } \\
\text { ocean models } \\
\text { normalised to } \\
\text { observations } \\
\text { with constant } \\
\text { delta }\end{array}$ & $\begin{array}{l}\text { First use of } \\
\text { five DGVMs to } \\
\text { compare with } \\
\text { budget residual }\end{array}$ & \\
\hline $\begin{array}{l}2010 \\
\text { Friedlingstein et al. (2010) }\end{array}$ & $\begin{array}{l}\text { Projection for } \\
\text { current year } \\
\text { based on GDP }\end{array}$ & $\begin{array}{l}\text { Emissions for } \\
\text { top emitters }\end{array}$ & & $\begin{array}{l}E_{\text {LUC }} \text { updated } \\
\text { with FAO-FRA } \\
2010\end{array}$ & & & & \\
\hline $\begin{array}{l}2011 \\
\text { Peters et al. (2012) }\end{array}$ & & & $\begin{array}{l}\text { Split between } \\
\text { Annex B and } \\
\text { non-Annex B }\end{array}$ & & & & & \\
\hline $\begin{array}{l}2012 \\
\text { Le Quéré et al. (2013), Pe- } \\
\text { ters et al. (2013) }\end{array}$ & & $\begin{array}{l}129 \text { countries } \\
\text { from } 1959\end{array}$ & $\begin{array}{l}129 \text { countries } \\
\text { and regions } \\
\text { from 1990- } \\
2010 \text { based on } \\
\text { GTAP8.0 }\end{array}$ & $\begin{array}{l}E_{\text {LUC for }} \\
1997-2011 \text { in- } \\
\text { cludes interan- } \\
\text { nual anomalies } \\
\text { from fire-based } \\
\text { emissions }\end{array}$ & $\begin{array}{l}\text { All years from } \\
\text { global average }\end{array}$ & $\begin{array}{l}\text { Based on five } \\
\text { ocean models } \\
\text { normalised to } \\
\text { observations } \\
\text { with ratio }\end{array}$ & $\begin{array}{l}\text { Nine DGVMs } \\
\text { available for } \\
S_{\text {LAND; first }} \\
\text { use of four } \\
\text { models to } \\
\text { compare with } \\
E_{\text {LUC }}\end{array}$ & \\
\hline $\begin{array}{l}2013 \\
\text { (this study) }\end{array}$ & & 250 countries $^{b}$ & $\begin{array}{l}134 \text { countries } \\
\text { and regions } \\
\text { 1990-2011 } \\
\text { based on } \\
\text { GTAP8.1 }\end{array}$ & $\begin{array}{l}E_{\text {LUC }} \text { for } 2012 \\
\text { estimated from } \\
\text { 2001-2010 } \\
\text { average }\end{array}$ & & $\begin{array}{l}\text { Based on six } \\
\text { models }\end{array}$ & $\begin{array}{l}\text { Coordinated } \\
\text { DGVM } \\
\text { experiments } \\
\text { for } S_{\text {LAND }} \text { and } \\
E_{\text {LUC }}\end{array}$ & $\begin{array}{l}\text { Confidence levels; } \\
\text { cumulative } \\
\text { emissions; } \\
\text { budget from } 1750\end{array}$ \\
\hline
\end{tabular}

emissions except to the extent that they are captured in the UN energy data and counted as gas "flared or lost".

The published CDIAC data set has 250 countries and regions included. This expanded list includes countries that no longer exist, such as the USSR or East Pakistan. For the budget, we reduce the list to 219 countries by reallocating emissions to the currently defined territories. This involved both aggregation and disaggregation, and does not change global emissions. Examples of aggregation include merging East and West Germany to the currently defined Germany. Examples of disaggregation include reallocating the emissions from the former USSR to the resulting independent countries. For disaggregation, we use the emission shares when the current territory first appeared. For the 2 most recent years, 2011 and 2012, the BP statistics are more aggregated, but we retain the detail in CDIAC by applying the same growth rates to individual countries in CDIAC as in the aggregated regions in the BP data set.
Estimates of $\mathrm{CO}_{2}$ emissions show that the global total of emissions is not equal to the sum of emissions from all countries. This is largely attributable to emissions that occur in international territory, in particular the combustion of fuels used in international shipping and aviation (bunker fuels), where the emissions are included in the global totals but are not attributed to individual countries. In practice, the emissions from international bunker fuels are calculated based on where the fuels were loaded, but they are not included with national emissions estimates. Smaller differences occur because globally the sum of imports in all countries is not equal to the sum of exports and because of differing treatment of oxidation of non-fuel uses of hydrocarbons (e.g. as solvents, lubricants, feedstocks, etc.), and changes in stock (Andres et al., 2012).

The uncertainty of the annual fossil-fuel and cement emissions for the globe has been estimated at $\pm 5 \%$ (scaled down from the published $\pm 10 \%$ at $\pm 2 \sigma$ to the use of $\pm 1 \sigma$ bounds reported here; Andres et al., 2012). This includes an 
Table 4. Data sources used to compute each component of the global carbon budget.

\begin{tabular}{|c|c|c|c|}
\hline Component & Process & Data source & Data reference \\
\hline \multirow[t]{3}{*}{$E_{\mathrm{FF}}$} & $\begin{array}{l}\text { Fossil-fuel combustion and gas } \\
\text { flaring }\end{array}$ & UN Statistics Division to 2010 & $\mathrm{UN}(2012 \mathrm{a}, \mathrm{b})$ \\
\hline & & BP for 2011-2012 & BP (2013) \\
\hline & Cement production & US Geological Survey & $\begin{array}{l}\text { van Oss (2013) } \\
\text { US Geological Survey (2012) }\end{array}$ \\
\hline \multirow[t]{5}{*}{$E_{\text {LUC }}$} & $\begin{array}{l}\text { Land cover change (deforesta- } \\
\text { tion, afforestation, and forest } \\
\text { regrowth) }\end{array}$ & $\begin{array}{l}\text { Forest Resource Assessment } \\
\text { (FRA) of the Food and } \\
\text { Agriculture Organisation } \\
\text { (FAO) }\end{array}$ & FAO (2010) \\
\hline & Wood harvest & FAO Statistics Division & FAOSTAT (2010) \\
\hline & Shifting agriculture & FAO FRA and Statistics & FAO $(2010)$ \\
\hline & & Division & FAOSTAT (2010) \\
\hline & $\begin{array}{l}\text { Interannual variability from } \\
\text { peat fires and climate-land } \\
\text { management interactions } \\
(2001-2010)\end{array}$ & $\begin{array}{l}\text { Global Fire Emissions } \\
\text { Database (GFED3) }\end{array}$ & Giglio et al. (2010) \\
\hline \multirow[t]{5}{*}{$G_{\mathrm{ATM}}$} & $\begin{array}{l}\text { Change in atmospheric } \mathrm{CO}_{2} \\
\text { concentration }\end{array}$ & $\begin{array}{l}\text { 1959-1980: } \mathrm{CO}_{2} \text { Program at } \\
\text { Scripps Institution of Oceanog- } \\
\text { raphy and other research groups }\end{array}$ & Keeling et al. (1976) \\
\hline & & 1980-2011: US National & Dlugokencky and Tans (2013) \\
\hline & & Oceanic and Atmospheric & Ballantyne et al. (2012) \\
\hline & & Administration Earth System & \\
\hline & & Research Laboratory & \\
\hline \multirow[t]{5}{*}{$S_{\text {OCEAN }}$} & Uptake of anthropogenic $\mathrm{CO}_{2}$ & 1990-1999 average: indirect es- & Manning and Keeling (2006) \\
\hline & & timates based on CFCs, atmo- & McNeil et al. (2003) \\
\hline & & $\begin{array}{l}\text { spheric } \mathrm{O}_{2} \text {, and other tracer ob- } \\
\text { servations }\end{array}$ & $\begin{array}{l}\text { Mikaloff Fletcher et al. (2006) } \\
\text { as assessed by the IPCC }\end{array}$ \\
\hline & & & Denman et al. (2007) \\
\hline & $\begin{array}{l}\text { Impact of increasing } \\
\text { atmospheric } \mathrm{CO}_{2} \text {, and climate } \\
\text { change and variability }\end{array}$ & Ocean models & Table 6 \\
\hline$S_{\text {LAND }}$ & $\begin{array}{l}\text { Response of land vegetation to: } \\
\text { Increasing atmospheric } \mathrm{CO}_{2} \\
\text { concentration } \\
\text { Climate change and variability } \\
\text { Other environmental changes }\end{array}$ & Budget residual & \\
\hline
\end{tabular}

assessment of uncertainties in the amounts of fuel consumed, the carbon contents of fuels, and the combustion efficiency. While in the budget we consider a fixed uncertainty of $\pm 5 \%$ for all years, in reality the uncertainty, as a percentage of the emissions, is growing with time because of the larger share of global emissions from non-Annex B countries (emerging economies and developing countries) with less precise statistical systems (Marland et al., 2009). For example, the uncertainty in Chinese emissions has been estimated at around $\pm 10 \%$ (for $\pm 1 \sigma$; Gregg et al., 2008). Generally, emissions from mature economies with good statistical bases have an uncertainty of only a few per cent (Marland, 2008). Further research is needed before we can quantify the time evolution of the uncertainty, and their temporal error correlation structure. We note that even if they are presented as $1 \sigma$ estimates, uncertainties of emissions are likely to be mainly countryspecific systematic errors related to underlying biases of energy statistics and to the accounting method used by each country. We assign a medium confidence to the results presented here because they are based on indirect estimates of emissions using energy data (Durant et al., 2010). Thus there is only limited and indirect evidence for emissions, although there is a high agreement among the available estimates within the given uncertainty (Andres et al., 2012), and 
the emission estimates are consistent with a range of other observations (Ciais et al., 2013).

\subsubsection{Emissions embodied in goods and services}

National emission inventories take a territorial (production) perspective and "include greenhouse gas emissions and removals taking place within national territory and offshore areas over which the country has jurisdiction" (Rypdal et al., 2006). That is, emissions are allocated to the country where and when the emissions actually occur. The territorial emission inventory of an individual country does not include the emissions from the production of goods and services produced in other countries (e.g. food and clothes) that are used for consumption. Consumption-based emission inventories for an individual country is another attribution point of view that allocates global emissions to products that are consumed within a country; these are conceptually calculated as the territorial emissions less the "embedded" territorial emissions to produce exported products plus the emissions in other countries to produce imported products (Consumption $=$ Territorial - Exports + Imports). The difference between the territorial- and consumption-based emission inventories is the net transfer (exports minus imports) of emissions from the production of internationally traded products. Consumption-based emission attribution results (e.g. Davis and Caldeira, 2010) provide additional information to territorial inventories that can be used to understand emission drivers (Hertwich and Peters, 2009), quantify emission transfers by the trade of products between countries (Peters et al., 2011b) and potentially design more effective and efficient climate policy (Peters and Hertwich, 2008).

We estimate consumption-based emissions by enumerating the global supply chain using a global model of the economic relationships between sectors within and between every country (Andrew and Peters, 2013; Peters et al., 2011a). Due to the availability of the input data, detailed estimates are made for the years 1997, 2001, 2004, and 2007 (using the methodology of Peters et al., 2011b) using economic and trade data from the Global Trade and Analysis Project version 8.1 (GTAP; Narayanan et al., 2013). The results cover 57 sectors and 134 countries and regions. The results are extended into an annual time series from 1990 to the latest year of the fossil-fuel emissions or GDP data (2011 in this budget), using GDP data by expenditure in current USD (from the UN National Accounts main Aggregrates database; UN, 2013c) and time series of trade data from GTAP (based on the methodology in Peters et al., 2011b).

The consumption-based emission inventories in this carbon budget incorporate several improvements over previous versions (Le Quéré et al., 2013; Peters et al., 2012b, 2011b). The detailed estimates for 2004 and 2007 and time series approximation from 1990-2011 are based on an updated version of the GTAP database (Narayanan et al., 2013). We estimate the sector level $\mathrm{CO}_{2}$ emissions using our own calcula- tions based on the GTAP data and methodology, include flaring and cement emissions from CDIAC, and then scale the national totals (excluding bunker fuels) to match the CDIAC estimates from the most recent carbon budget. We do not include international transportation in our estimates of national totals, but include them in the global total. The time series of trade data provided by GTAP covers the period 1995-2009 and our methodology uses the trade shares of this data set. For the period 1990-1994 we assume the trade shares of 1995, while in 2010 and 2011 we assume the trade shares of 2008 , since 2009 was heavily affected by the global financial crisis. We identified errors in the trade shares of Taiwan in 2008 and 2009, so the trade shares for 2008-2010 are based on the 2007 trade shares.

We do not provide an uncertainty estimate for these emissions, but based on model comparisons and sensitivity analysis, they are unlikely to be larger than for the territorial emission estimates (Peters et al., 2012a). Uncertainty is expected to increase for more detailed results, and to decrease with aggregation (Peters et al., 2011b; e.g. the results for Annex B will be more accurate than the sector results for an individual country).

The consumption-based emissions attribution method considers the $\mathrm{CO}_{2}$ emitted to the atmosphere in the production of products, but not the trade in fossil fuels (coal, oil, gas). It is also possible to account for the carbon trade in fossil fuels (Davis et al., 2011), but we do not present that data here. Peters et al. (2012a) additionally consider trade in biomass.

The consumption data do not modify the global average terms in Eq. (1), but are relevant to the anthropogenic carbon cycle, as they reflect the trade-driven movement of carbon across the earth's surface in response to human activities (both physical for carbon trade in fossil fuels and economic for emissions embedded into products). Furthermore, if national and international climate policies continue to develop in an un-harmonised way, then the trends reflected in these data will need to be accommodated by those developing policies.

\subsubsection{Growth rate in emissions}

We report the annual growth rate in emissions for adjacent years (in per cent per year) by calculating the difference between the 2 years and then comparing to the emissions in the first year: $\left[\frac{\left.E_{\mathrm{FF}\left(\mathrm{t}_{0}+1\right.}\right)^{-E_{\mathrm{FF}\left(\mathrm{t}_{0}\right)}}}{E_{\mathrm{FF}\left(\mathrm{t}_{0}\right)}}\right] \% \mathrm{yr}^{-1}$. This is the simplest method to characterise a 1-year growth compared to the previous year and is widely used. We do not apply a leapyear adjustment, which could affect the growth rate by about $0.3 \% \mathrm{yr}^{-1}(1 / 365.25)$.

The relative growth rate of $E_{\mathrm{FF}}$ over time periods of greater than 1 year can be rewritten using its logarithm equivalent as follows:

$\frac{1}{E_{\mathrm{FF}}} \frac{\mathrm{d} E_{\mathrm{FF}}}{\mathrm{d} t}=\frac{\mathrm{d}\left(\ln E_{\mathrm{FF}}\right)}{\mathrm{d} t}$. 
Here we calculate relative growth rates in emissions for multi-year periods (e.g. a decade) by fitting a linear trend to $\ln \left(E_{\mathrm{FF}}\right)$ in Eq. (2), reported in per cent per year. We fit the logarithm of $E_{\mathrm{FF}}$ rather than $E_{\mathrm{FF}}$ directly because this method ensures that computed growth rates satisfy Eq. (6). This method differs from previous papers (Canadell et al., 2007; Le Quéré et al., 2009; Raupach et al., 2007) that computed the fit to $E_{\mathrm{FF}}$ and divided by average $E_{\mathrm{FF}}$ directly, but the difference is very small $(<0.05 \%)$ in the case of $E_{\mathrm{FF}}$.

\subsubsection{Emissions projections using GDP projections}

Energy statistics are normally available around June for the previous year. We use the close relationship between the growth in world gross domestic product (GDP) and the growth in global emissions (Raupach et al., 2007) to project emissions for the current year. This is based on the so-called Kaya identity (also called IPAT identity for human impact (I) on the environment equaling the product of $P=$ population, $A=$ affluence, $T=$ technology), whereby $E_{\mathrm{FF}}$ is decomposed by the product of GDP and the fossil-fuel carbon intensity of the economy $\left(I_{\mathrm{FF}}\right)$ as follows:

$E_{\mathrm{FF}}=\mathrm{GDP} \times I_{\mathrm{FF}}$.

Such product-rule decomposition identities imply that the growth rates of the multiplied quantities are additive. Taking a time derivative of Eq. (3) gives:

$\frac{\mathrm{d} E_{\mathrm{FF}}}{\mathrm{d} t}=\frac{\mathrm{d}\left(\mathrm{GDP} \times I_{\mathrm{FF}}\right)}{\mathrm{d} t}$

and applying the rules of calculus:

$\frac{\mathrm{d} E_{\mathrm{FF}}}{\mathrm{d} t}=\frac{\mathrm{dGDP}}{\mathrm{d} t} \times I_{\mathrm{FF}}+\mathrm{GDP} \times \frac{\mathrm{d} I_{\mathrm{FF}}}{\mathrm{d} t}$

finally, dividing (5) by (3) gives :

$\frac{1}{E_{\mathrm{FF}}} \frac{\mathrm{d} E_{\mathrm{FF}}}{\mathrm{d} t}=\frac{1}{\mathrm{GDP}} \frac{\mathrm{dGDP}}{\mathrm{d} t}+\frac{1}{I_{\mathrm{FF}}} \frac{\mathrm{d} I_{\mathrm{FF}}}{\mathrm{d} t}$,

where the left-hand term is the relative growth rate of $E_{\mathrm{FF}}$, and the right-hand terms are the relative growth rates of GDP and $I_{\mathrm{FF}}$, respectively, which can simply be added linearly to give overall growth rate. The growth rates are reported in per cent by multiplying each term by 100 . As preliminary estimates of annual change in GDP are made well before the end of a calendar year, making assumptions on the growth rate of $I_{\mathrm{FF}}$ allows us to make projections of the annual change in $\mathrm{CO}_{2}$ emissions well before the end of a calendar year.

\section{2 $\mathrm{CO}_{2}$ emissions from land use, land-use change and forestry $\left(E_{\mathrm{LUC}}\right)$}

LUC emissions reported in the 2013 carbon budget ( $E_{\mathrm{LUC}}$ ) include $\mathrm{CO}_{2}$ fluxes from deforestation, afforestation, logging (forest degradation and harvest activity), shifting cultivation (cycle of cutting forest for agriculture, then abandoning), and regrowth of forests following wood harvest or abandonment of agriculture. Only some land management activities (Table 5) are included in our LUC emissions estimates (e.g. emissions or sinks related to management of established pasture and croplands are not included). Some of these activities lead to emissions of $\mathrm{CO}_{2}$ to the atmosphere, while others lead to $\mathrm{CO}_{2}$ sinks. $E_{\mathrm{LUC}}$ is the net sum of all anthropogenic activities considered. Our annual estimate for 1959-2010 is from a bookkeeping method (Sect. 2.2.1) primarily based on net forest area change and biomass data from the Forest Resource Assessment (FRA) of the Food and Agriculture Organization (FAO) which is only available at intervals of 5 years (Houghton et al., 2012). Interannual variability in emissions due to deforestation and degradation have been coarsely estimated from satellite-based fire activity in tropical forest areas (Sect. 2.2.2; Giglio et al., 2010; van der Werf et al., 2010). The bookkeeping method is used mainly to quantify the $E_{\mathrm{LUC}}$ over the time period of the available data, and the satellite-based deforestation fire information to reveal interannual variability due to tropical deforestation fires. The satellite-based deforestation and degradation fire emissions estimates are available for years 1997-2011. We calculate the global anomaly in deforestation and degradation fire emissions over tropical forest regions for each year, compared to the 1997-2010 period, and add this to the $E_{\mathrm{LUC}}$ estimated using the bookkeeping method which is available up to 2010 only. For 2011 we use the 2011 anomaly from the fire data, with the mean emission from the bookkeeping method over 1997 to 2010. We thus assume that all land management activities apart from deforestation and degradation do not vary significantly on a year-to-year basis. Other sources of interannual variability (e.g. the impact of climate variability on regrowth fluxes and shifting agriculture $\mathrm{CO}_{2}$ fluxes)

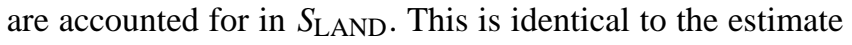
presented in Le Quéré et al. (2013), except for a small update in the bookkeeping estimate from revisions in the data (Sect. 2.2.1). Fire emissions were not available for year 2012. $E_{\mathrm{LUC}}$ for 2012 is thus assigned the mean of 2001-2010 (last decade where the bookkeeping method is available) and a low confidence. In addition, we use results from nine dynamic global vegetation models (see Sect. 2.2.3 and Table 6) that calculate net $\mathrm{LUC} \mathrm{CO}_{2}$ emissions in response to observed land cover change prescribed to each model, to help quantify the uncertainty in $E_{\mathrm{LUC}}$, and to explore the consistency of our understanding. The three methods are described below, and differences are discussed in Sect. 3.2.

\subsubsection{Bookkeeping method}

LUC $\mathrm{CO}_{2}$ emissions are calculated by a bookkeeping model approach (Houghton, 2003) that keeps track of the carbon stored in vegetation and soils before deforestation or other land-use change, and the changes in forest age classes, or cohorts, of disturbed lands after land-use change. It tracks the $\mathrm{CO}_{2}$ emitted to the atmosphere immediately during deforestation, and over time due to the follow-up decay of soil and 
Table 5. Comparison of the processes included in the $E_{\mathrm{LUC}}$ of the global carbon budget and the DGVMs. See Table 6 for model references. All models include deforestation and forest regrowth after abandonment of agriculture (or from afforestation activities on agricultural land).

\begin{tabular}{|c|c|c|c|c|c|c|c|c|c|c|}
\hline & Bookkeeping & CLM4.5BGC & ISAM & JULES & LPJ-GUESS & LPJ & LPX-Bern & $\mathrm{O}-\mathrm{CN}$ & ORCHIDEE & VISIT \\
\hline Wood harvest and forest degradation ${ }^{a}$ & yes & yes & yes & no & no & no & no & no & no & yes $^{\mathrm{b}}$ \\
\hline Shifting cultivation & yes & yes & no & no & no & no & no & no & no & yes \\
\hline Cropland harvest & yes & yes & no & no & yes & no & yes & yes & yes & yes \\
\hline Peat fires & no & yes & no & no & no & no & no & no & no & no \\
\hline Fire simulation and/or suppression & for US only & yes & no & no & yes & yes & yes & no & no & yes \\
\hline Climate change and variability & no & yes & yes & yes & yes & yes & yes & yes & yes & yes \\
\hline $\mathrm{CO}_{2}$ fertilisation & no & yes & yes & yes & yes & yes & yes & yes & yes & yes \\
\hline $\begin{array}{l}\text { Carbon-nitrogen interactions, } \\
\text { including } \mathrm{N} \text { deposition }\end{array}$ & no & yes & yes & no & no & no & yes & yes & no & no \\
\hline
\end{tabular}

vegetation carbon in different pools, including wood products pools after logging and deforestation. It also tracks the regrowth of vegetation and associated build-up of soil carbon pools. It considers transitions between forests, pastures and cropland, shifting cultivation, degradation of forests where a fraction of the trees are removed, abandonment of agricultural land, and forest management such as wood harvest and, in the USA, fire management. In addition to tracking logging debris on the forest floor, the bookkeeping model tracks the fate of carbon contained in harvested wood products that is eventually emitted back to the atmosphere as $\mathrm{CO}_{2}$, although a detailed treatment of the lifetime in each product pool is not performed (Earles et al., 2012). Harvested wood products are partitioned into three pools with different turnover times. All fuel-wood is assumed burnt in the year of harvest $\left(1.0 \mathrm{yr}^{-1}\right)$. Pulp and paper products are oxidised at a rate of $0.1 \mathrm{yr}^{-1}$, timber is assumed to be oxidised at a rate of $0.01 \mathrm{yr}^{-1}$, and elemental carbon decays at $0.001 \mathrm{yr}^{-1}$. The general assumptions about partitioning wood products among these pools are based on national harvest data (Houghton, 2003).

The primary land cover change and biomass data for the bookkeeping model analysis is the Forest Resource Assessment of the FAO which provides statistics on forest cover change and management at intervals of 5 years (FAO, 2010). The data are based on countries' self-reporting, some of which include satellite data in more recent assessments (Table 4). Changes in land cover other than forest are based on annual, national changes in cropland and pasture areas reported by the FAO Statistics Division (FAOSTAT, 2010). LUC country data are aggregated by regions. The carbon stocks on land (biomass and soils), and their response functions subsequent to LUC, are based on FAO data averages per land cover type, per biome and per region. Similar results were obtained using forest biomass carbon density based on satellite data (Baccini et al., 2012). The bookkeeping model does not include land ecosystems' transient response to changes in climate, atmospheric $\mathrm{CO}_{2}$ and other environmental factors, but the growth/decay curves are based on contemporary data that will implicitly reflect the effects of $\mathrm{CO}_{2}$ and climate at that time. Results from the bookkeeping method are available from 1850 to 2010 .

\subsubsection{Fire-based method}

LUC-associated $\mathrm{CO}_{2}$ emissions calculated from satellitebased fire activity in tropical forest areas (van der Werf et al., 2010) provide information on emissions due to tropical deforestation and degradation that are complementary to the bookkeeping approach. They do not provide a direct estimate of $E_{\mathrm{LUC}}$ as they do not include non-combustion processes such as respiration, wood harvest, wood products or forest regrowth. Legacy emissions such as decomposition from onground debris and soils are not included in this method either. However, fire estimates provide some insight on the yearto-year variations in the sub-component of the total $E_{\mathrm{LUC}}$ flux that result from immediate $\mathrm{CO}_{2}$ emissions during deforestation caused by the interactions between climate and human activity (e.g. there is more burning and clearing of forests in dry years) that are not represented by other methods. The "deforestation fire emissions" assume an important role of fire in removing biomass in the deforestation process, and thus can be used to infer gross instantaneous $\mathrm{CO}_{2}$ emissions from deforestation using satellite-derived data on fire activity in regions with active deforestation. The method requires information on the fraction of total area burned associated with deforestation versus other types of fires, and can be merged with information on biomass stocks and the fraction of the biomass lost in a deforestation fire to estimate $\mathrm{CO}_{2}$ emissions. The satellite-based fire emissions are limited to the tropics, where fires result mainly from human activities. Tropical deforestation is the largest and most variable single contributor to $E_{\mathrm{LUC}}$.

Burned area from Giglio et al. (2010) is merged with active fire retrievals to mimic more sophisticated assessments of deforestation rates in the pan-tropics (van der Werf et al., 2010). This information is used as input data in a modified version of the satellite-driven Carnegie Ames Stanford Approach (CASA) biogeochemical model to estimate carbon emissions, keeping track of what fraction was due to deforestation (van der Werf et al., 2010). The CASA model uses different assumptions to compute decay functions compared to the bookkeeping model, and does not include historical emissions or regrowth from land-use change prior to the 
Table 6. References for the process models and data products included in Fig. 3.

\begin{tabular}{|c|c|c|}
\hline Model/Data name & Reference & Change from Le Quéré et al. (2013) \\
\hline \multicolumn{3}{|c|}{ Dynamic global vegetation models } \\
\hline CLM4.5BGC $^{\mathrm{a}}$ & Oleson et al. (2013) & $\begin{array}{l}\text { Updated model from CLM4.0CN to CLM4.5BGC. Major changes in- } \\
\text { clude revised photosynthesis, slower turnover times for decomposition } \\
\text { of litter and SOM, vertically resolved soil biogeochemistry, revised soil } \\
\text { denitrification and nitrification, new fire model, and revised frozen-soil } \\
\text { hydrology. As shown in Koven et al. (2013), these changes collectively } \\
\text { bring the model into better agreement with the 20th-century C budget. } \\
\text { not applicable }\end{array}$ \\
\hline JULES ${ }^{\mathrm{c}}$ & Clarke et al. $(2011)^{\mathrm{d}}$ & $\begin{array}{l}\text { Updated model from JULESv1 (Cox et al., 2000) to JULESv3.2 as } \\
\text { configured in the latest generation ESM-HadGEM2-ES (Collins et al., } \\
2011 \text { ). Higher resolution }(1.875 \times 1.25) \text { and with an improved snow } \\
\text { scheme, multi-pool soil carbon model, updated representation of land- } \\
\text { use change. }\end{array}$ \\
\hline LPJ-GUESS & Smith et al. (2001) & not applicable \\
\hline $\mathrm{LPJ}^{\mathrm{e}}$ & Sitch et al. (2003) & $\begin{array}{l}\text { Decreased LPJ wood harvest efficiency so that } 50 \% \text { of biomass was re- } \\
\text { moved off-site compared to } 85 \% \text { used in the } 2012 \text { budget. Residue man- } \\
\text { agement of managed grasslands increased so that } 100 \% \text { of harvested } \\
\text { grass enters the litter pool. }\end{array}$ \\
\hline LPX-Bern & Stocker et al. (2013a) & Addition of $\mathrm{C}-\mathrm{N}$ cycle coupling. \\
\hline $\mathrm{O}-\mathrm{CN}$ & Zaehle \& Friend $(2010)^{\mathrm{f}}$ & $\begin{array}{l}\text { Update of baseline land-cover data set to Jung et al. (2006) and a shift } \\
\text { from coarse resolution, monthly meteorological forcing to daily meteo- } \\
\text { rological forcing. }\end{array}$ \\
\hline ORCHIDEE & Krinner et al. (2005) & $\begin{array}{l}\text { Revised parameters values for photosynthetic capacity for boreal forests } \\
\text { (following assimilation of FLUXNET data), updated parameters val- } \\
\text { ues for stem allocation, maintenance respiration and biomass export for } \\
\text { tropical forests (based on literature) and, } \mathrm{CO}_{2} \text { down-regulation process } \\
\text { added to photosynthesis. }\end{array}$ \\
\hline VISIT & Kato et al. (2013) ${ }^{\mathrm{g}}$ & $\begin{array}{l}\text { Wood harvest flux is added to } E_{\mathrm{LUC}} \text {, and the loss of additional sink } \\
\text { capacity is also included in the } E_{\mathrm{LUC}} \text { due to the methodological change } \\
\text { of using coordinated DGVM experiments. }\end{array}$ \\
\hline \multicolumn{3}{|c|}{ Data products for land-use change emissions } \\
\hline $\begin{array}{l}\text { Bookkeeping } \\
\text { Fire-based emissions }\end{array}$ & $\begin{array}{l}\text { Houghton et al. (2012) } \\
\text { van der Werf et al. (2010) }\end{array}$ & $\begin{array}{l}\text { not applicable } \\
\text { not applicable }\end{array}$ \\
\hline \multicolumn{3}{|c|}{ Ocean Biogeochemistry Models } \\
\hline NEMO-PlankTOM5 & Buitenhuis et al. $(2010)^{\mathrm{h}}$ & no change \\
\hline LSCE & $\begin{array}{l}\text { Aumont and Bopp } \\
(2006)\end{array}$ & no change \\
\hline CCSM-BEC & Doney et al. (2009) & no change \\
\hline МICOM-НАMOCC & Assmann et al. $(2010)^{\mathrm{i}}$ & no change \\
\hline MPIOM-HAMOCC & IIyina et al. (2013) & no change \\
\hline BLING $^{\mathrm{j}}$ & Galbraith (2009) & no change \\
\hline \multicolumn{3}{|c|}{ Data products for ocean $\mathrm{CO}_{2}$ sink } \\
\hline Park & Park et al. $(2010)^{\mathrm{k}}$ & not applicable \\
\hline Rödenbeck & Rödenbeck et al. (2014) & not applicable \\
\hline
\end{tabular}

${ }^{\mathrm{a}}$ Community Land Model 4.5, ${ }^{\mathrm{b}}$ see also El-Masri et al. (2013), ${ }^{\mathrm{c}}$ Joint UK Land Environment Simulator, ${ }^{\mathrm{d}}$ see also Best et al. (2011), ${ }^{\mathrm{e}}$ Lund-Potsdam-Jena, ${ }^{\mathrm{f}}$ see also Zaehle et al. (2010), ${ }^{\mathrm{g}}$ see also Ito and Inatomi (2012), ${ }^{\mathrm{h}}$ with no nutrient restoring below the mixed layer depth, ${ }^{\mathrm{i}}$ with updates to the physical model as described in Tjiputra et al. (2013), ${ }^{\mathrm{j}}$ available to year 2008 only, ${ }^{\mathrm{k}}$ using winds from Atlas et al. (2011), ${ }^{\mathrm{l}}$ updated version "oc_v1.2". 
availability of satellite data. Comparing coincident $\mathrm{CO}$ emissions and their atmospheric fate with satellite-derived $\mathrm{CO}$ concentrations allows for some validation of this approach (e.g. van der Werf et al., 2008). Results from the fire-based method are available from 1997 to 2011 only. Our combination of $\mathrm{LUC} \mathrm{CO}_{2}$ emissions where the variability of instantaneous $\mathrm{CO}_{2}$ deforestation emissions is diagnosed from fires assumes that year-to-year variability is dominated by variability in deforestation due to the large carbon losses involved.

\subsubsection{Dynamic global vegetation models (DGVMs)}

LUC $\mathrm{CO}_{2}$ emissions have been estimated using an ensemble of nine DGVMs (from four in the 2012 carbon budget). New model experiments up to year 2012 have been coordinated by the project "Trends and drivers of the regionalscale sources and sinks of carbon dioxide" (TRENDY; http: //dgvm.ceh.ac.uk/node/9). We use only models that have estimated $\mathrm{LUC} \mathrm{CO}_{2}$ emissions and the terrestrial residual sink following the TRENDY protocol (see Sect. 2.5.2), thus providing better consistency in the assessment of the causes of carbon fluxes on land. Models use their latest configurations, summarised in Tables 5 and 6 .

The DGVMs were forced with historical changes in land cover distribution, climate, atmospheric $\mathrm{CO}_{2}$ concentration, and $\mathrm{N}$ deposition. As further described below, each historical DGVM simulation was repeated with a time-invariant preindustrial land cover distribution, allowing to estimate, by difference with the first simulation, the dynamic evolution of biomass and soil carbon pools in response to prescribed land cover change. All DGVMs represent deforestation and (to some extent) regrowth, the most important components of $E_{\text {LUC }}$, but they do not represent all processes resulting directly from human activities on land (Table 5). DGVMs represent processes of vegetation establishment, growth, mortality and decomposition associated with natural cycles and include the vegetation and soil response to increasing atmospheric $\mathrm{CO}_{2}$ levels, to climate variability and change, in addition to atmospheric $\mathrm{N}$ deposition in the presence of nitrogen limitation (in four models; Table 5). The DGVMs are independent from the other budget terms, except for their use of atmospheric $\mathrm{CO}_{2}$ concentration to calculate the fertilisation effect of $\mathrm{CO}_{2}$ on primary production.

The DGVMs used a consistent land-use change data set (Hurtt et al., 2011), which provided annual, half-degree, fractional data on cropland, pasture, primary vegetation and secondary vegetation, as well as all underlying transitions between land-use states, including wood harvest and shifting cultivation. This data set used the HYDE (Klein Goldewijk et al., 2011) spatially gridded maps of cropland, pasture, and ice/water fractions of each grid cell as an input. The HYDE data are based on annual FAO statistics of change in agricultural area (FAOSTAT, 2010). For the year 2012, the HYDE data set was extrapolated from 2011, based on the trend in agricultural area over the previous 5 years. The HYDE data set is independent from the data set used in the bookkeeping method (Houghton, 2003 and updates), which is based primarily on forest area change statistics (FAO, 2010). Although the Hurtt land-use change data set indicates whether landuse changes occur on forested or non-forested land, typically only the the changes in agricultural areas are used by the models and are implemented differently within each model (e.g. an increased cropland fraction in a grid cell can either be at the expense of grassland, or forest, the latter resulting in deforestation; land cover fractions of the non-agricultural land differ between models). Similarly, model-specific assumptions are also applied for the conversion of wood harvest mass or area and other product pools into carbon in some models (Table 5).

The DGVM model runs were forced by observed monthly temperature, precipitation, and cloud cover fields, provided on a $0.5^{\circ} \times 0.5^{\circ}$ grid and updated to 2012 by the Climatic Research Unit (Harris et al., 2013). The forcing data include both gridded observations of climate change and change in global atmospheric $\mathrm{CO}_{2}$ (Dlugokencky and Tans, 2013), and $\mathrm{N}$ deposition (as used in four models, Table 5; Lamarque et al., 2010). $E_{\mathrm{LUC}}$ is diagnosed in each model by the difference between a model simulation with prescribed historical land cover change and a simulation with constant, preindustrial land cover distribution. Both simulations were driven by changing atmospheric $\mathrm{CO}_{2}$, climate, and in some models $\mathrm{N}$ deposition over the period 1860-2012. Using the difference between these two DGVM simulations to diagnose $E_{\mathrm{LUC}}$ is not consistent with the definition of $E_{\mathrm{LUC}}$ in the bookkeeping model (Gasser and Ciais, 2013; Pongratz et al., 2013). The DGVM approach to diagnose land-use change $\mathrm{CO}_{2}$ emissions would be expected to produce systematically higher $E_{\mathrm{LUC}}$ emissions than the bookkeeping approach if all the parameters of the two approaches were the same (which is not the case). Here, given the different input data of DGVMs and the bookkeeping approach, this systematic difference cannot be quantified.

\subsubsection{Uncertainty assessment for $E_{\mathrm{LUC}}$}

Differences between the bookkeeping, the addition of firebased interannual variability to the bookkeeping, and DGVM methods originate from three main sources: the land cover change data set, different approaches in models, and in the different processes represented (Table 5). We examine the results from the nine DGVM models and of the bookkeeping method to assess the uncertainty in $E_{\mathrm{LUC}}$.

The uncertainties in the annual $E_{\mathrm{LUC}}$ estimates are examined using the standard deviation across models, which ranged from 0.3 to $0.9 \mathrm{GtC} \mathrm{yr}^{-1}$, with an average of $0.5 \mathrm{GtC} \mathrm{yr}^{-1}$ from 1959 to 2012 (Table 7). The mean of the multi-model $E_{\mathrm{LUC}}$ estimates is higher than the bookkeeping estimate used in the budget with a mean absolute difference of $0.3 \mathrm{GtC}$ for 1959 to 2010 . The multi-model mean and 
bookkeeping method differ by less than $0.5 \mathrm{GtC} \mathrm{yr}^{-1}$ over $85 \%$ of the time. Based on this comparison, we assess that an uncertainty of $\pm 0.5 \mathrm{GtC} \mathrm{yr}^{-1}$ provides a semi-quantitative measure of uncertainty for annual emissions, and reflects our best value judgment that there is at least a $68 \%$ chance $( \pm 1 \sigma)$ that the true LUC emission lies within the given range for the range of processes considered here. This is consistent with the analysis of Houghton et al. (2012), which partly reflects improvements in data on forest area change using satellite data, and partly more complete understanding and representation of processes in models.

The uncertainties in the decadal mean estimates from the DGVM ensemble are likely correlated between decades, and thus we apply the annual uncertainty as a measure of the decadal uncertainty. The correlations between decades come from (1) common biases in system boundaries (e.g. not counting forest degradation in some models); (2) common definition for the calculation of $E_{\mathrm{LUC}}$ from the difference of simulations with and without LUC (a source of bias vs. the unknown truth); (3) common and uncertain land-cover change input data which also cause a bias, though if a different input data set is used each decade, decadal fluxes from DGVMs may be partly decorrelated; and (4) model structural errors (e.g. systematic errors in biomass stocks). In addition, errors arising from uncertain DGVM parameter values would be random but they are not accounted for in this study, since no DGVM provided an ensemble of runs with perturbed parameters.

Prior to 1959 , the uncertainty in $E_{\mathrm{LUC}}$ is taken as $\pm 33 \%$, which is the ratio of uncertainty to mean from the 1960s (Table 7), the first decade available. This ratio is consistent with the mean standard deviation of DGVMs LUC emissions over the period 1901-1958 (0.42 GtC) over the multi-model mean $(1.3 \mathrm{GtC})$.

\subsection{Atmospheric $\mathrm{CO}_{2}$ growth rate $\left(G_{\mathrm{ATM}}\right)$}

\subsubsection{Global atmospheric $\mathrm{CO}_{2}$ growth rate estimates}

The atmospheric $\mathrm{CO}_{2}$ growth rate is provided by the US National Oceanic and Atmospheric Administration Earth System Research Laboratory (NOAA/ESRL; Dlugokencky and Tans, 2013), which is updated from Ballantyne et al. (2012). For the 1959-1980 period, the global growth rate is based on measurements of atmospheric $\mathrm{CO}_{2}$ concentration averaged from the Mauna Loa and South Pole stations, as observed by the $\mathrm{CO}_{2}$ Program at Scripps Institution of Oceanography (Keeling et al., 1976). For the 1980-2012 time period, the global growth rate is based on the average of multiple-station selected from the marine boundary layer sites with wellmixed background air (Ballantyne et al., 2012), after fitting each station with a smoothed curve as a function of time, and averaging by latitude band (Masarie and Tans, 1995). The annual growth rate is estimated from atmospheric $\mathrm{CO}_{2}$ concentration by taking the average of the most recent December-
January months corrected for the average seasonal cycle and subtracting this same average one year earlier. The growth rate in units of $\mathrm{ppm} \mathrm{yr}^{-1}$ is converted to fluxes by multiplying by a factor of $2.120 \mathrm{GtC}$ per ppm (Prather et al., 2012) for comparison with the other components.

The uncertainty around the annual growth rate based on the multiple stations data set ranges between 0.11 and $0.72 \mathrm{GtC} \mathrm{yr}^{-1}$, with a mean of $0.60 \mathrm{GtC} \mathrm{yr}^{-1}$ for $1959-1980$ and $0.19 \mathrm{GtC} \mathrm{yr}^{-1}$ for $1980-2012$, when a larger set of stations were available. It is based on the number of available stations, and thus takes into account both the measurement errors and data gaps at each station. This uncertainty is larger than the uncertainty of $\pm 0.1 \mathrm{GtC} \mathrm{yr}^{-1}$ reported for decadal mean growth rate by the IPCC because errors in annual growth rate are strongly anti-correlated in consecutive years, leading to smaller errors for longer timescales. The decadal change is computed from the difference in concentration 10 years apart based on a measurement error of $0.35 \mathrm{ppm}$. This error is based on offsets between NOAA/ESRL measurements and those of the World Meteorological Organization World Data Center for Greenhouse Gases (NOAA/ESRL, 2013) for the start and end points (the decadal change uncertainty is the $\sqrt{\left(2 *(0.35 \mathrm{ppm})^{2}\right)} 10$ years $^{-1}$ assuming that each yearly measurement error is independent). This uncertainty is also used in Table 8.

The contribution of anthropogenic $\mathrm{CO}$ and $\mathrm{CH}_{4}$ is neglected from the global carbon budget (see Sect. 2.6.1). We assign a high confidence to the annual estimates of $G_{\text {ATM }}$ because they are based on direct measurements from multiple and consistent instruments and stations distributed around the world (Ballantyne et al., 2012).

In order to estimate the total carbon accumulated in the atmosphere since 1750 or 1870 , we use an atmospheric $\mathrm{CO}_{2}$ concentration of $277 \pm 3 \mathrm{ppm}$ or $288 \pm 3 \mathrm{ppm}$, respectively, based on a cubic spline fit to ice core data (Joos and Spahni, 2008). The uncertainty of $\pm 3 \mathrm{ppm}$ (converted to $\pm 1 \sigma$ ) is taken directly from the IPCC's assessment (Ciais et al., 2013). Typical uncertainties in the atmospheric growth rate from ice core data are $\pm 1-1.5 \mathrm{GtC}$ per decade, as evaluated from the Law Dome data (Etheridge et al., 1996) for individual 20-year intervals over the period 1870-1960 (Bruno and Joos, 1997).

\subsection{Ocean $\mathrm{CO}_{2}$ sink}

Estimates of the global ocean $\mathrm{CO}_{2}$ sink are based on a combination of a mean $\mathrm{CO}_{2}$ sink estimate for the 1990s from observations, and a trend and variability in the ocean $\mathrm{CO}_{2}$ sink for 1959-2012 from six global ocean biogeochemistry models. Observation-based products that estimate the annual $\mathrm{CO}_{2}$ sink are beginning to emerge. These are used here for the first time to provide a qualitative assessment of confidence in the reported results. 
Table 7. Comparison of results from the bookkeeping model and budget residuals with results from the DGVMs for the periods 1960-1969, 1970-1979, 1980-1989, 1990-1999, 2000-2009 and the last decade-available. All values are in GtC yr ${ }^{-1}$. The DGVM uncertainties represents $\pm 1 \sigma$ of results from the nine individual models.

\begin{tabular}{|c|c|c|c|c|c|c|c|}
\hline & \multicolumn{7}{|c|}{ Mean $\left(\mathrm{GtC} \mathrm{yr}^{-1}\right)$} \\
\hline & 1960-1969 & $1970-1979$ & 1980-1989 & 1990-1999 & $2000-2009$ & 2003-2012 & 2012 \\
\hline \multicolumn{8}{|l|}{ Land-use change emissions ( $\left.E_{\mathrm{LUC}}\right)$} \\
\hline Bookkeeping method & $1.5 \pm 0.5$ & $1.3 \pm 0.5$ & $1.4 \pm 0.5$ & $1.5 \pm 0.5$ & $1.0 \pm 0.5$ & $1.0 \pm 0.5^{*}$ & $1.0 \pm 0.5^{*}$ \\
\hline DGVMs & $1.6 \pm 0.5$ & $1.4 \pm 0.4$ & $1.5 \pm 0.4$ & $2.0 \pm 0.7$ & $1.3 \pm 0.5$ & $1.1 \pm 0.5$ & $0.6 \pm 0.7$ \\
\hline \multicolumn{8}{|l|}{ Residual terrestrial sink ( $\left.S_{\text {LAND }}\right)$} \\
\hline Budget residual & $1.7 \pm 0.7$ & $1.7 \pm 0.8$ & $1.6 \pm 0.8$ & $2.6 \pm 0.7$ & $2.4 \pm 0.8$ & $2.8 \pm 0.8$ & $2.7 \pm 0.9$ \\
\hline DGVMs & $1.2 \pm 0.7$ & $2.1 \pm 0.7$ & $1.6 \pm 0.8$ & $2.1 \pm 0.8$ & $2.5 \pm 0.8$ & $2.6 \pm 0.9$ & $1.8 \pm 1.1$ \\
\hline
\end{tabular}

${ }^{*} E_{\text {LUC }}$ for 2012 is assigned the mean of 2001-2010 as the estimate based on the bookkeeping method was not available for that year.

Table 8. Decadal mean in the five components of the anthropogenic $\mathrm{CO}_{2}$ budget for the periods 1960-1969, 1970-1979, 1980-1989,

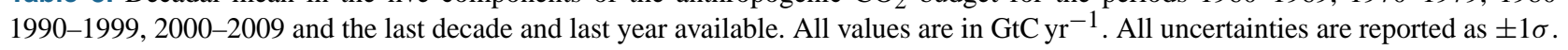

\begin{tabular}{|c|c|c|c|c|c|c|c|}
\hline & \multicolumn{7}{|c|}{ Mean $\left(\mathrm{GtC} \mathrm{yr}^{-1}\right)$} \\
\hline & 1960-1969 & 1970-1979 & 1980-1989 & 1990-1999 & $2000-2009$ & 2003-2012 & 2012 \\
\hline \multicolumn{8}{|l|}{ Emissions } \\
\hline $\begin{array}{l}\text { Fossil-fuel combustion } \\
\text { and cement production }\left(E_{\mathrm{FF}}\right)\end{array}$ & $3.1 \pm 0.2$ & $4.7 \pm 0.2$ & $5.5 \pm 0.3$ & $6.4 \pm 0.3$ & $7.9 \pm 0.4$ & $8.6 \pm 0.4$ & $9.7 \pm 0.5$ \\
\hline Land-use change emissions ( $\left.E_{\mathrm{LUC}}\right)$ & $1.5 \pm 0.5$ & $1.3 \pm 0.5$ & $1.4 \pm 0.5$ & $1.6 \pm 0.5$ & $1.0 \pm 0.5$ & $0.9 \pm 0.5^{\mathrm{a}}$ & $1.0 \pm 0.5^{\mathrm{a}}$ \\
\hline \multicolumn{8}{|l|}{ Partitioning } \\
\hline $\begin{array}{l}\text { Atmospheric growth } \\
\text { rate }\left(G_{\mathrm{ATM}}\right)\end{array}$ & $1.7 \pm 0.1$ & $2.8 \pm 0.1$ & $3.4 \pm 0.1$ & $3.1 \pm 0.1$ & $4.0 \pm 0.1$ & $4.3 \pm 0.1$ & $5.1 \pm 0.2$ \\
\hline Ocean sink $\left(S_{\text {OCEAN }}\right)^{\mathrm{b}}$ & $1.2 \pm 0.5$ & $1.5 \pm 0.5$ & $1.9 \pm 0.5$ & $2.2 \pm 0.4$ & $2.4 \pm 0.5$ & $2.5 \pm 0.5$ & $2.9 \pm 0.5$ \\
\hline Residual terrestrial sink ( $\left.S_{\text {LAND }}\right)$ & $1.7 \pm 0.7$ & $1.7 \pm 0.8$ & $1.6 \pm 0.8$ & $2.6 \pm 0.7$ & $2.4 \pm 0.8$ & $2.8 \pm 0.8$ & $2.7 \pm 0.9$ \\
\hline
\end{tabular}

\subsubsection{Observation-based estimates}

A mean ocean $\mathrm{CO}_{2}$ sink of $2.2 \pm 0.4 \mathrm{GtC} \mathrm{yr}^{-1}$ for the $1990 \mathrm{~s}$ was estimated by the IPCC (Denman et al., 2007) based on indirect observations and their spread: ocean/land $\mathrm{CO}_{2}$ sink partitioning from observed atmospheric $\mathrm{O}_{2} / \mathrm{N}_{2}$ concentration trends (Manning and Keeling, 2006), an oceanic inversion method constrained by ocean biogeochemistry data (Mikaloff Fletcher et al., 2006), and a method based on penetration timescale for CFCs (McNeil et al., 2003). This is comparable with the sink of $2.0 \pm 0.5 \mathrm{GtC} \mathrm{yr}^{-1}$ estimated by Khatiwala et al. (2013) for the 1990s, and with the sink of 1.9 to 2.5 estimated from a range of methods for the period 1990-2009 (Wanninkhof et al., 2013), with uncertainties ranging from $\pm 0.3 \mathrm{GtC} \mathrm{yr}^{-1}$ to $\pm 0.7 \mathrm{GtC} \mathrm{yr}^{-1}$.

The interannual variability in the ocean $\mathrm{CO}_{2}$ sink was estimated for 1990-2011 by Rödenbeck et al. (2014, version "oc_v1.2") using an inversion method based on observed oceanic partial pressure of $\mathrm{CO}_{2}\left(p \mathrm{CO}_{2}\right)$ derived from the Surface Ocean $\mathrm{CO}_{2}$ Atlas (SOCAT v2), a database of qualitycontrolled surface ocean fugacity of $\mathrm{CO}_{2}\left(p \mathrm{CO}_{2}\right.$ corrected for the non-ideal behaviour of the gas; Bakker et al., 2014;
Pfeil et al., 2013). Interannual variability in ocean $\mathrm{CO}_{2}$ was also estimated with an update of Park et al. (2010) based on regional correlations between surface temperature and $p \mathrm{CO}_{2}$, changes in surface temperature observed by satellite, and wind speed estimates also from satellite data for 1990 2009 (Atlas et al., 2011). This estimate provides a data-based assessment of the interannual variability combined with a model-based assessment of the trend and mean in $S_{\text {OCEAN. }}$.

We use the data-based product of Khatiwala et al. (2009) updated by Khatiwala et al. (2013) to estimate the anthropogenic carbon accumulated in the ocean during the period 1765-1958 (60.2 GtC) and 1870-1958 (47.5 GtC), and assume an oceanic uptake of $0.4 \mathrm{GtC}$ for $1750-1765$ where no data are available based on the mean uptake during the period 1765-1770. The estimate of Khatiwala et al. (2009) is based on regional disequilibrium between surface $p \mathrm{CO}_{2}$ and atmospheric $\mathrm{CO}_{2}$, and a Green's function utilising transient ocean tracers like $\mathrm{CFCs}$ and ${ }^{14} \mathrm{C}$ to ascribe changes through time. It does not include changes associated with changes in ocean circulation, temperature and climate, but these are thought to be small over the time period considered here (Ciais et 
al., 2013). The uncertainty in cumulative uptake of $\pm 20 \mathrm{GtC}$ (converted to $\pm 1 \sigma$ ) is taken directly from the IPCC's review of the literature (Rhein et al., 2013), or about $\pm 30 \%$ for the annual values (Khatiwala et al., 2009).

\subsubsection{Global ocean biogeochemistry models}

The trend in the ocean $\mathrm{CO}_{2}$ sink for 1959-2012 is computed using a combination of six global ocean biogeochemistry models (Table 6). The models represent the physical, chemical and biological processes that influence the surface ocean concentration of $\mathrm{CO}_{2}$ and thus the air-sea $\mathrm{CO}_{2}$ flux. The models are forced by meteorological reanalysis data and atmospheric $\mathrm{CO}_{2}$ concentration available for the entire time period. Models do not include the effects of anthropogenic changes in nutrient supply. They compute the air-sea flux of $\mathrm{CO}_{2}$ over grid boxes of 1 to $4^{\circ}$ in latitude and longitude. The ocean $\mathrm{CO}_{2}$ sink for each model is normalised to the observations, by dividing the annual model values by their observed average over 1990-1999, and multiplying this by the observation-based estimate of $2.2 \mathrm{GtC} \mathrm{yr}^{-1}$. The ocean $\mathrm{CO}_{2}$ sink for each year $(t)$ is therefore

$S_{\text {OCEAN }}(t)=\frac{1}{n} \sum_{m=1}^{m=n} \frac{S_{\text {OCEAN }}^{m}(t)}{S_{\text {OCEAN }}^{m}(1990-1999)} \times 2.2$,

where $n$ is the number of models. This normalisation ensures that the ocean $\mathrm{CO}_{2}$ sink for the global carbon budget is based on observations, and that the trends and annual values in $\mathrm{CO}_{2}$ sinks are consistent with model estimates. The normalisation based on a ratio assumes that if models overor underestimate the sink in the 1990s, it is primarily due to the process of diffusion, which depends on the gradient of $\mathrm{CO}_{2}$. Thus a ratio is more appropriate than an offset as it takes into account the time-dependence of $\mathrm{CO}_{2}$ gradients in the ocean. We use the four models published in Le Quéré et al. (2009), including updates, of Aumont and Bopp (2006), Doney et al. (2009), Buitenhuis et al. (2010), and Galbraith et al. (2010) and further model estimates updated from Assman et al. (2010) and Ilyina et al. (2013); see Table 6. All models are available to 2012 except Galbraith et al. (2010), which is available to 2008. The mean uncorrected ocean $\mathrm{CO}_{2}$ sink from the six models for 1990-1999 ranges between 1.5 and 2.6 $\mathrm{GtC} \mathrm{yr}^{-1}$, with a multi-model mean of $2.1 \mathrm{GtC} \mathrm{yr}^{-1}$.

\subsubsection{Uncertainty assessment for $S_{\text {OCEAN }}$}

The uncertainty around the mean ocean sink of anthropogenic $\mathrm{CO}_{2}$ was already quantified for the 1990s (see Sect. 2.4.1). To quantify the uncertainty around annual values, we examine the standard deviation of the normalised model ensemble. We use further information from the two data-based products to assess the confidence level. The standard deviation of the ocean model ensemble averages to $0.13{\mathrm{GtC} \mathrm{yr}^{-1}}^{-1}$ during the period 1980-2010 (with a maximum of 0.22), but it increases as the model ensemble goes back in time, with a standard deviation of $0.29 \mathrm{GtC} \mathrm{yr}^{-1}$ across models in the $1960 \mathrm{~s}$. We estimate that the uncertainty in the annual ocean $\mathrm{CO}_{2}$ sink is about $\pm 0.5 \mathrm{GtC} \mathrm{yr}^{-1}$ from the quadratic sum of the data uncertainty of $\pm 0.4 \mathrm{GtC} \mathrm{yr}^{-1}$ and standard deviation across models of up to $\pm 0.29 \mathrm{GtC} \mathrm{yr}^{-1}$, reflecting both the uncertainty in the mean sink and in the interannual variability as assessed by models.

We examine the consistency between the variability of the model-based and the data-based products to assess confidence in $S_{\text {OCEAN. The interannual variability of the }}$ ocean fluxes of the two data-based estimates for 1990-2009 (when they overlap) is $\pm 0.35 \mathrm{GtC} \mathrm{yr}^{-1}$ (Rödenbeck et al., 2014) and $\pm 0.14 \mathrm{GtC} \mathrm{yr}^{-1}$ (Park et al., 2010), compared to $\pm 0.20 \mathrm{GtC} \mathrm{yr}^{-1}$ for the model mean. The phase is generally consistent between estimates, with a higher ocean $\mathrm{CO}_{2}$ sink during El Niño events. The two data-based estimates correlate with the ocean $\mathrm{CO}_{2}$ sink estimated here with the same correlation of $r=0.59$ (simple linear regression), but with a mutual correlation between data-based estimates of 0.30 only. A comparison of variability in regional fluxes also shows generally consistent patterns in amplitude, although not everywhere in phase (not shown). We assess a medium confidence level to the annual ocean $\mathrm{CO}_{2}$ sink and its uncertainty because they are based on multiple lines of evidence, and the results are consistent in that the interannual variability in the model and data-based estimates are both generally small and consistent in time, but nevertheless not in high agreement.

\subsection{Terrestrial $\mathrm{CO}_{2}$ sink}

The difference between the fossil-fuel $\left(E_{\mathrm{FF}}\right)$ and LUC net emissions $\left(E_{\mathrm{LUC}}\right)$, the growth rate in atmospheric $\mathrm{CO}_{2}$ concentration $\left(G_{\mathrm{ATM}}\right)$ and the ocean $\mathrm{CO}_{2} \operatorname{sink}\left(S_{\text {OCEAN }}\right)$ is attributable to the net sink of $\mathrm{CO}_{2}$ in terrestrial vegetation and soils $\left(S_{\mathrm{LAND}}\right)$, within the given uncertainties. Thus, this sink can be estimated either as the residual of the other terms in the mass balance budget but also directly calculated using DGVMs. The residual land sink $\left(S_{\text {LAND }}\right)$ is in part due to the fertilising effect of rising atmospheric $\mathrm{CO}_{2}$ on plant growth, $\mathrm{N}$ deposition and climate change effects, such as the lengthening of the growing season in northern temperate and boreal areas. $S_{\text {LAND }}$ does not include gross land sinks directly resulting from LUC (e.g. regrowth of vegetation) as these are estimated as part of the net land use flux $\left(E_{\mathrm{LUC}}\right)$. System boundaries make it difficult to attribute exact $\mathrm{CO}_{2}$ fluxes on land between $S_{\text {LAND }}$ and $E_{\text {LUC }}$ (Erb et al., 2013), and by design most of the uncertainties in our method are allocated to $S_{\text {LAND }}$ for those processes that are poorly known or represented in models. 


\subsubsection{Residual of the budget}

For 1959-2012, the terrestrial carbon sink was estimated from the residual of the other budget terms by rearranging Eq. (1):

$S_{\mathrm{LAND}}=E_{\mathrm{FF}}+E_{\mathrm{LUC}}-\left(G_{\mathrm{ATM}}+S_{\mathrm{OCEAN}}\right)$.

The uncertainty in $S_{\text {LAND }}$ is estimated annually from the quadratic sum of the uncertainty in the right-hand terms assuming the errors are not correlated. The uncertainty averages to $\pm 0.8{\mathrm{GtC} \mathrm{yr}^{-1}}^{-1}$ over 1959-2012 (Table 7). $S_{\text {LAND }}$ estimated from the residual of the budget includes, by definition, all the missing processes and potential biases in the other components of Eq. (8).

\subsubsection{DGVMs}

A comparison of the residual calculation of $S_{\text {LAND }}$ in Eq. (8) with the same DGVMs used to estimate $E_{\text {LUC }}$ in Sect. 2.2.3, but here excluding the effects of changes in land cover (using a constant preindustrial land cover distribution), provides an independent estimate of the consistency of $S_{\text {LAND }}$ with our understanding of the functioning of the terrestrial vegetation in response to $\mathrm{CO}_{2}$ and climate variability (Table 7). As described in Sect. 2.2.3, the DGVM runs that exclude the effects of changes in land cover include all climate variability and $\mathrm{CO}_{2}$ effects over land, but do not include reductions in $\mathrm{CO}_{2}$ sink capacity associated with human activity directly affecting changes in vegetation cover and management, which by design is allocated to $E_{\mathrm{LUC}}$. This effect has been estimated to have led to a reduction in the terrestrial

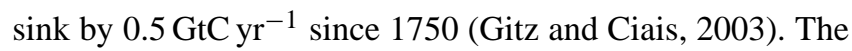
models estimate the mean and variability of $S_{\text {LAND }}$ based on atmospheric $\mathrm{CO}_{2}$ and climate, and thus both terms can be compared to the budget residual.

The multi-model DGVM mean of $2.6 \pm 0.9 \mathrm{GtC} \mathrm{yr}^{-1}$ for the period 2003-2012 agrees well with the value computed from the budget residual (Table 7). The standard deviation of the annual $\mathrm{CO}_{2}$ sink across the nine DGVMs ranges from \pm 0.3 to $\pm 1.2 \mathrm{GtC} \mathrm{yr}^{-1}$, with a mean standard deviation of $\pm 0.8 \mathrm{GtC} \mathrm{yr}^{-1}$ for the period 1959-2012. The model mean correlates with the budget residual with $r=0.73$, compared to correlations of $r=0.47$ to $r=0.71$ (median of 0.65 ) by individual models. The standard deviation is similar to that of the five model ensembles presented in Le Quéré et al. (2009), but the correlation is improved compared to $r=0.54 \mathrm{ob}-$ tained in the earlier study. The DGVM results confirm that the sum of our knowledge on annual $\mathrm{CO}_{2}$ emissions and their partitioning is plausible (see Discussion), and they enable the attribution of the fluxes to the underlying processes and provide a breakdown of the regional contributions (not shown here). However as the standard deviation across the DGVMs ( of $\pm 0.8 \mathrm{GtC} \mathrm{yr}^{-1}$ ) is of the same magnitude as the combined uncertainty due to the other components ( $E_{\mathrm{FF}}, E_{\mathrm{LUC}}, G_{\mathrm{ATM}}$, $S_{\text {OCEAN }}$; Table 7 ), the DGVMs do not provide further reduc- tion of uncertainty on the terrestrial $\mathrm{CO}_{2}$ sink compared to the residual of the budget (Eq. 8). Yet, DGVM results are largely independent from the residual of the budget, and it is worth noting that the residual method and DGVM results are consistent within their respective uncertainties. We assess a medium confidence level to the annual land $\mathrm{CO}_{2}$ sink and its uncertainty because the estimates from the residual budget and DGVMs match well within the given uncertainty, and the estimates based on the residual budget are primarily dependent on $E_{\mathrm{FF}}$ and $G_{\mathrm{ATM}}$, both of which are well constrained.

\subsection{Processes not included in the global carbon budget \\ 2.6.1 Contribution of anthropogenic $\mathrm{CO}$ and $\mathrm{CH}_{4}$ to the global carbon budget}

Anthropogenic emissions of $\mathrm{CO}$ and $\mathrm{CH}_{4}$ to the atmosphere are eventually oxidised to $\mathrm{CO}_{2}$ and thus are part of the global carbon budget. These contributions are omitted in Eq. (1), but an attempt is made in this section to estimate their magnitude, and identify the sources of uncertainty. Anthropogenic $\mathrm{CO}$ emissions are from incomplete fossil-fuel and biofuel burning and deforestation fires. The main anthropogenic emissions of fossil $\mathrm{CH}_{4}$ that matter for the global carbon budget are the fugitive emissions of coal, oil and gas upstream sectors (see below). These emissions of $\mathrm{CO}$ and $\mathrm{CH}_{4}$ contribute a net addition of fossil carbon to the atmosphere.

In our estimate of $E_{\mathrm{FF}}$ we assume that all the fuel burned is emitted as $\mathrm{CO}_{2}$, thus $\mathrm{CO}$ emissions and their atmospheric oxidation into $\mathrm{CO}_{2}$ within a few months are already counted implicitly in $E_{\mathrm{FF}}$ and should not be counted twice (same for $E_{\text {LUC }}$ and $\mathrm{CO}$ deforestation fires). Anthropogenic emissions of fossil $\mathrm{CH}_{4}$ are not included in the fossil-fuel $\mathrm{CO}_{2}$ emissions $E_{\mathrm{FF}}$, because these mainly fugitive emissions are not included in fuel inventories, but they contribute to the carbon budget after $\mathrm{CH}_{4}$ gets oxidised into $\mathrm{CO}_{2}$ (lifetime 9.1 years; Masson-Delmotte et al., 2013). These anthropogenic fossil $\mathrm{CH}_{4}$ emissions are estimated to be $0.07 \mathrm{GtC} \mathrm{yr}^{-1}$ [0.060.09] (after Kirschke et al., 2013). After 1 year, $89 \%$ of these emissions thus remain in the atmosphere as $\mathrm{CH}_{4}$ and contribute to the observed $\mathrm{CH}_{4}$ global growth rate but not to the $\mathrm{CO}_{2}$ growth rate, whereas the rest $(11 \%)$ gets oxidised into $\mathrm{CO}_{2}$, and contributes to the $\mathrm{CO}_{2}$ growth rate. Given that anthropogenic fossil-fuel $\mathrm{CH}_{4}$ emissions represent a fraction of $15 \%$ of the total global $\mathrm{CH}_{4}$ source (Kirschke et al., 2013) we assumed that a fraction of $0.15 \times 0.92$ of the observed global growth rate of $\mathrm{CH}_{4}$ of $6 \mathrm{TgC} \mathrm{yr}^{-1}$ during the period 2000-2009 is due to fossil $\mathrm{CH}_{4}$ sources. Therefore, annual fossil-fuel $\mathrm{CH}_{4}$ emissions contribute $0.8{\mathrm{TgC} \mathrm{yr}^{-1}}^{-1}$ the $\mathrm{CH}_{4}$ growth rate and $0.8 \mathrm{TgC} \mathrm{yr}^{-1}$ (units of $\mathrm{C}$ in $\mathrm{CO}_{2}$ form) to the $\mathrm{CO}_{2}$ growth rate. Summing up the effect of fossil-fuel $\mathrm{CH}_{4}$ emissions from each previous year during the past 10 years, a fraction of which is oxidised into $\mathrm{CO}_{2}$ in the current year, this defines a contribution of $5 \mathrm{TgC}^{-1}$ to the $\mathrm{CO}_{2}$ growth rate, or about $0.1 \%$. Thus the effect of 
anthropogenic fossil $\mathrm{CH}_{4}$ emissions and their oxidation to $\mathrm{CO}_{2}$ in the atmosphere can be assessed to have a negligible effect on the observed $\mathrm{CO}_{2}$ growth rate, although they do contribute significantly to the global $\mathrm{CH}_{4}$ growth rate.

Other anthropogenic biogenic sources of $\mathrm{CO}$ and $\mathrm{CH}_{4}$ from wildfires, biomass, wetlands or permafrost changes are similarly assumed to have a small effect on the $\mathrm{CO}_{2}$ growth rate.

\subsubsection{Anthropogenic carbon fluxes in the land to ocean continuum}

The approach used to determine the global carbon budget considers only anthropogenic $\mathrm{CO}_{2}$ emissions and their partitioning among the atmosphere, ocean and land. In analysis, the land and ocean reservoirs that take up anthropogenic $\mathrm{CO}_{2}$ from the atmosphere are conceived as independent carbon storage repositories. This approach thus omits that carbon is continuously displaced along the land-ocean aquatic continuum (LOAC) comprising freshwaters, estuaries and coastal areas. Carbon is transferred both in inorganic (bicarbonates and dissolved $\mathrm{CO}_{2}$ ), and organic (dissolved and particulate organic carbon) forms along this continuum. During its journey from upland terrestrial ecosystems to the oceans, carbon is not only transferred laterally, but is also sequestered in, for example, freshwater and coastal sediments (Krumins et al., 2013; Tranvik et al., 2009) or released back to the atmosphere, mainly as respired $\mathrm{CO}_{2}$ (Aufdenkampe et al., 2011; Battin et al., 2009; Cole et al., 2007; Laruelle et al., 2010; Regnier et al., 2013), and to a much lesser extent, as $\mathrm{CH}_{4}$ (Bastviken et al., 2011; Borges and Abril, 2011). A significant fraction of this lateral carbon flux is entirely "natural" and is thus a steady-state component of the preindustrial carbon cycle that can be ignored in the current analysis. The remaining fraction is anthropogenic carbon entrained into the lateral transport loop of the LOAC, a perturbation that is relevant for the global carbon budget presented here.

The recent synthesis by Regnier et al. (2013) is the first attempt to estimate the anthropogenic component of LOAC carbon fluxes and their significance for the global carbon budget. The results of their analysis can be summarised in three points of relevance to the budget. First, only a portion of the anthropogenic $\mathrm{CO}_{2}$ taken up by land ecosystems is sequestered in soil and biomass pools, as $1 \pm 0.5 \mathrm{GtC} \mathrm{yr}^{-1}$ is exported to the LOAC. This flux is comparable to the $\mathrm{C}$ released into the atmosphere by LUC (Table 8). Second, the exported anthropogenic carbon is both stored $\left(0.55 \pm 0.3 \mathrm{GtC} \mathrm{yr}^{-1}\right)$ and released back into the atmosphere as $\mathrm{CO}_{2}\left(0.35 \pm 0.2 \mathrm{GtC} \mathrm{yr}^{-1}\right)$, the magnitude of these fluxes resulting from the combined effects of freshwaters, estuaries and coastal seas. Third, a small fraction of anthropogenic carbon displaced by the LOAC accumulates in the open ocean $\left(0.1 \pm>0.05 \mathrm{GtC} \mathrm{yr}^{-1}\right)$. The anthropogenic perturbation of the carbon fluxes from land to ocean does not contradict the method used in Sect. 2.5 to define the ocean

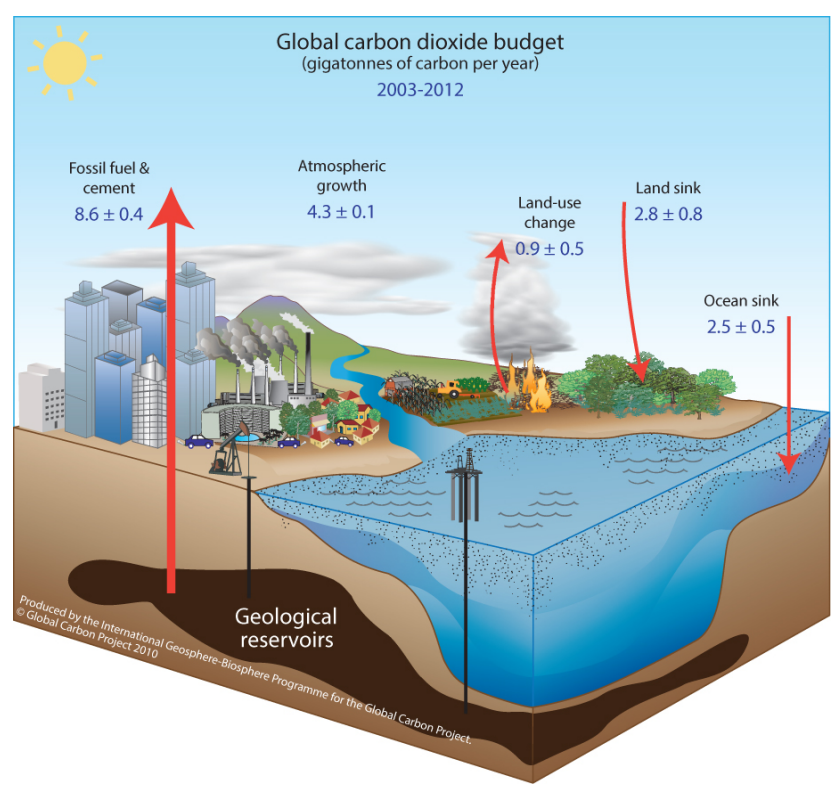

Figure 1. Schematic representation of the overall perturbation of the global carbon cycle caused by anthropogenic activities, averaged globally for the decade 2003-2012. The arrows represent emission from fossil-fuel burning and cement production $\left(E_{\mathrm{FF}}\right)$; emissions from deforestation and other land-use change $\left(E_{\mathrm{LUC}}\right)$; the growth of carbon in the atmosphere $\left(G_{\mathrm{ATM}}\right)$ and the uptake of carbon by the "sinks" in the ocean $\left(S_{\text {OCEAN }}\right)$ and land $\left(S_{\text {LAND }}\right)$ reservoirs. All fluxes are in units of $\mathrm{GtC} \mathrm{yr}^{-1}$, with uncertainties reported as $\pm 1 \sigma(68 \%$ confidence that the real value lies within the given interval) as described in the text. This figure is an update of one prepared by the International Geosphere Biosphere Programme for the GCP, first presented in Le Quéré (2009).

sink and residual land sink. However, it does point to the need to account for the fate of anthropogenic carbon once it is removed from the atmosphere by land ecosystems (summarised in Fig. 1). In theory, direct estimates of changes of the ocean inorganic carbon inventory over time would see the land flux of anthropogenic carbon and would thus have a bias relative to air-sea flux estimates and tracer based reconstructions. However, currently the value is small enough to be not noticeable relative to the errors in the individual techniques.

Of greater importance is the finding that the residual land sink calculated in a budget which accounts for the LOAC $\left(3.15 \pm 0.9 \mathrm{GtC} \mathrm{yr}^{-1}\right)$ is larger than the value of $2.8 \pm 0.8 \mathrm{GtC} \mathrm{yr}^{-1}$ reported in Table 7 , because this flux is partially offset by the net source of $\mathrm{CO}_{2}$ to the atmosphere of $0.35 \pm 0.3 \mathrm{GtC} \mathrm{yr}^{-1}$ from rivers, estuaries and coastal seas. In addition, because anthropogenic $\mathrm{CO}_{2}$ taken up by land ecosystems is exported to the LOAC, the annual land carbon storage change $\left(1.25 \mathrm{GtC} \mathrm{yr}^{-1}\right)$ is notably smaller than the net $\mathrm{CO}_{2}$ uptake by land ecosystems calculated in the GCP budget $\left(1.9 \mathrm{GtC} \mathrm{yr}^{-1}\right)$, a significant fraction of the displaced carbon $\left(0.65 \mathrm{GtC} \mathrm{yr}^{-1}\right)$ being stored in freshwater and 
coastal sediments $\left(0.55 \mathrm{GtC} \mathrm{yr}^{-1}\right)$, and to a lesser extent, in the open ocean $\left(0.1 \mathrm{GtC} \mathrm{yr}^{-1}\right)$.

All estimates of LOAC are given with low confidence, because they originate from a single source. The carbon budget presented here implicitly incorporates the fluxes from

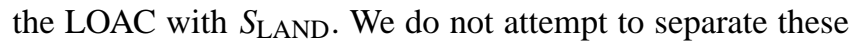
fluxes because the uncertainties in either estimate are too large, and there is insufficient information available to estimate the LOAC fluxes on an annual basis.

\section{Results}

\subsection{Global carbon budget averaged over decades and its variability}

The global carbon budget averaged over the last decade (2003-2012) is shown in Fig. 1. For this time period, 90\% of the total emissions $\left(E_{\mathrm{FF}}+E_{\mathrm{LUC}}\right)$ were caused by fossilfuel combustion and cement production, and $10 \%$ by landuse change. The total emissions were partitioned among the atmosphere (45\%), ocean (26\%) and land (29\%). All components except land-use change emissions have grown since 1959 (Figs. 2 and 3), with important interannual variability in the atmospheric growth rate and in the land $\mathrm{CO}_{2} \operatorname{sink}$ (Fig. 3), and some decadal variability in all terms (Table 8).

Global $\mathrm{CO}_{2}$ emissions from fossil-fuel combustion and cement production have increased every decade from an average of $3.1 \pm 0.2 \mathrm{GtC} \mathrm{yr}^{-1}$ in the 1960 s to an average of $8.6 \pm 0.4 \mathrm{GtC} \mathrm{yr}^{-1}$ during the period 2003-2012 (Table 8 and Fig. 4). The growth rate in these emissions decreased between the 1960s and the $1990 \mathrm{~s}$, from $4.5 \% \mathrm{yr}^{-1}$ in the $1960 \mathrm{~s}$, $2.7 \% \mathrm{yr}^{-1}$ in the $1970 \mathrm{~s}, 2.0 \% \mathrm{yr}^{-1}$ in the $1980 \mathrm{~s}, 1.1 \% \mathrm{yr}^{-1}$ in the 1990s, and began increasing again in the 2000s at an average growth rate of $3.1 \% \mathrm{yr}^{-1}$, decreasing slightly, to $2.7 \% \mathrm{yr}^{-1}$ for the last decade (2003-2012). In contrast, $\mathrm{CO}_{2}$ emissions from LUC have remained constant at around $1.5 \pm 0.5 \mathrm{GtC} \mathrm{yr}^{-1}$ between 1960 and 1999, and decreased to $1.0 \pm 0.5 \mathrm{GtC} \mathrm{yr}^{-1}$ between 2003 and 2012. The $E_{\mathrm{LUC}}$ estimates from the bookkeeping method and the DGVM models are consistent within their respective uncertainties (Table 7 and Fig. 5). The decrease in emissions from LUC since 2000 is reproduced by the DGVMs (Fig. 5).

The growth rate in atmospheric $\mathrm{CO}_{2}$ increased from $1.7 \pm 0.1 \mathrm{GtC} \mathrm{yr}^{-1}$ in the 1960 s to $4.3 \pm 0.1 \mathrm{GtC} \mathrm{yr}^{-1}$ during the period 2003-2012 with important decadal variations (Table 8). The ocean $\mathrm{CO}_{2}$ sink increased from $1.2 \pm 0.5 \mathrm{GtC} \mathrm{yr}^{-1}$ in the $1960 \mathrm{~s}$ to $2.5 \pm 0.5 \mathrm{GtC} \mathrm{yr}^{-1}$ during the period 2003-2012, with interannual variations of the order of a few tenths of $\mathrm{GtC} \mathrm{yr}^{-1}$. The low uptake anomaly around year 2000 originates from multiple regions in all models (western equatorial Pacific, Southern Ocean and North Atlantic), and is caused by climate variability. The land $\mathrm{CO}_{2}$ sink increased from $1.7 \pm 0.7 \mathrm{GtC} \mathrm{yr}^{-1}$ in the 1960 s to $2.8 \pm 0.8 \mathrm{GtC} \mathrm{yr}^{-1}$ during the period 2003-2012, with important interannual variations of up to $2 \mathrm{GtC} \mathrm{yr}^{-1}$.

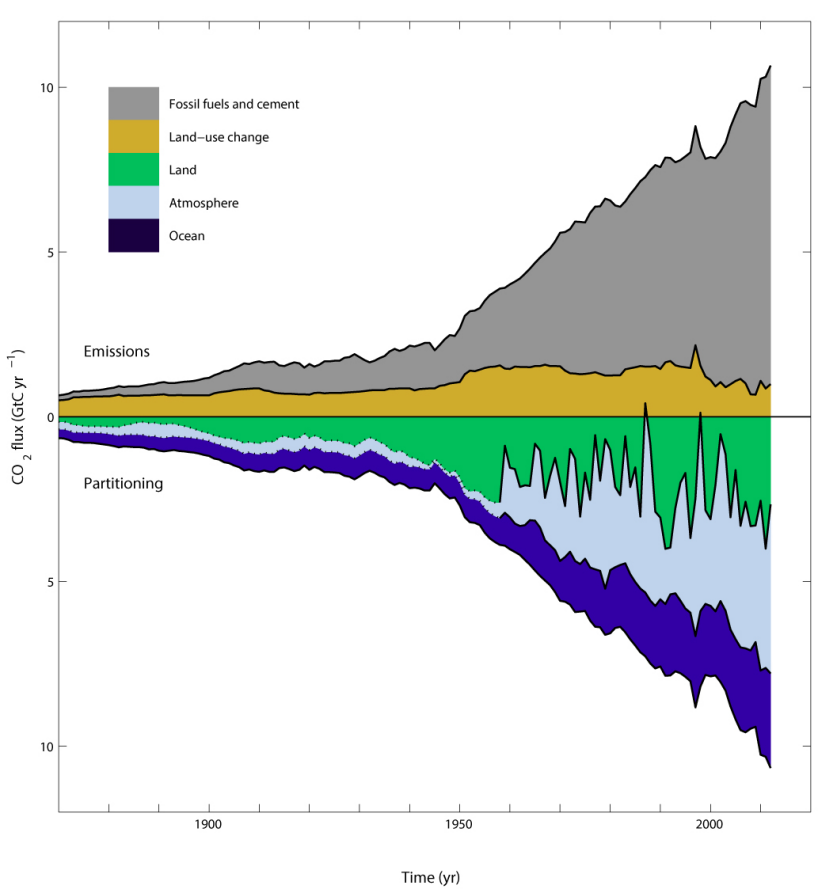

Figure 2. Combined components of the global carbon budget illustrated in Fig. 1 as a function of time, for (top) emissions from fossilfuel combustion and cement production $\left(E_{\mathrm{FF}}\right.$; grey) and emissions from land-use change $\left(E_{\mathrm{LUC}}\right.$; brown), and (bottom) their partitioning among the atmosphere $\left(G_{\mathrm{ATM}}\right.$; light blue), land $\left(S_{\mathrm{LAND}}\right.$; green) and oceans ( $S_{\text {OCEAN }}$; dark blue). All time series are in $\mathrm{GtC} \mathrm{yr}^{-1}$. $G_{\text {ATM }}$ and $S_{\text {OCEAN }}$ (and by construction also $S_{\text {LAND }}$ ) prior to 1959 are based on different methods and shown as a dashed line. The primary data sources are for fossil-fuel and cement emissions from Boden et al. (2013), with uncertainty of about $\pm 5 \%$ $( \pm 1 \sigma)$; land-use change emissions from Houghton et al. (2012) with uncertainties of about $\pm 30 \%$; atmospheric growth rate prior to 1959 is from Joos and Spahni (2008) with uncertainties of about $\pm 1-1.5 \mathrm{GtC} \mathrm{decade}^{-1}$ or $\pm 0.1-0.15 \mathrm{GtC} \mathrm{yr}^{-1}$ (Bruno and Joos, 1997), and from Dlugokencky and Tans (2013) from 1959 with uncertainties of about $\pm 0.2 \mathrm{GtC} \mathrm{yr}^{-1}$; ocean sink prior to 1959 is from Khatiwala et al. (2013) with uncertainty of about $\pm 30 \%$, and from this study from 1959 with uncertainties of about $\pm 0.5 \mathrm{GtC} \mathrm{yr}^{-1}$; residual land sink is obtained by difference (Eq. 8), resulting in uncertainties of about $\pm 50 \%$ prior to 1959 and $\pm 0.8 \mathrm{GtC} \mathrm{yr}^{-1}$ after that. See the text for more details of each component and their uncertainties.

The high uptake anomaly around year 1991 is thought to be caused by the effect of the volcanic eruption of Mount Pinatubo on climate and is not generally reproduced by the DGVMs (Fig. 5). The larger land $\mathrm{CO}_{2}$ sink during the period 2003-2012 is reproduced by the DGVMs in response to combined atmospheric $\mathrm{CO}_{2}$ increase and climate change and variability, fully consistent with the budget residual (Table 7). Both ocean and land $\mathrm{CO}_{2}$ sinks increased roughly in line with the atmospheric increase, but with significant decadal variability on land (Table 8). 

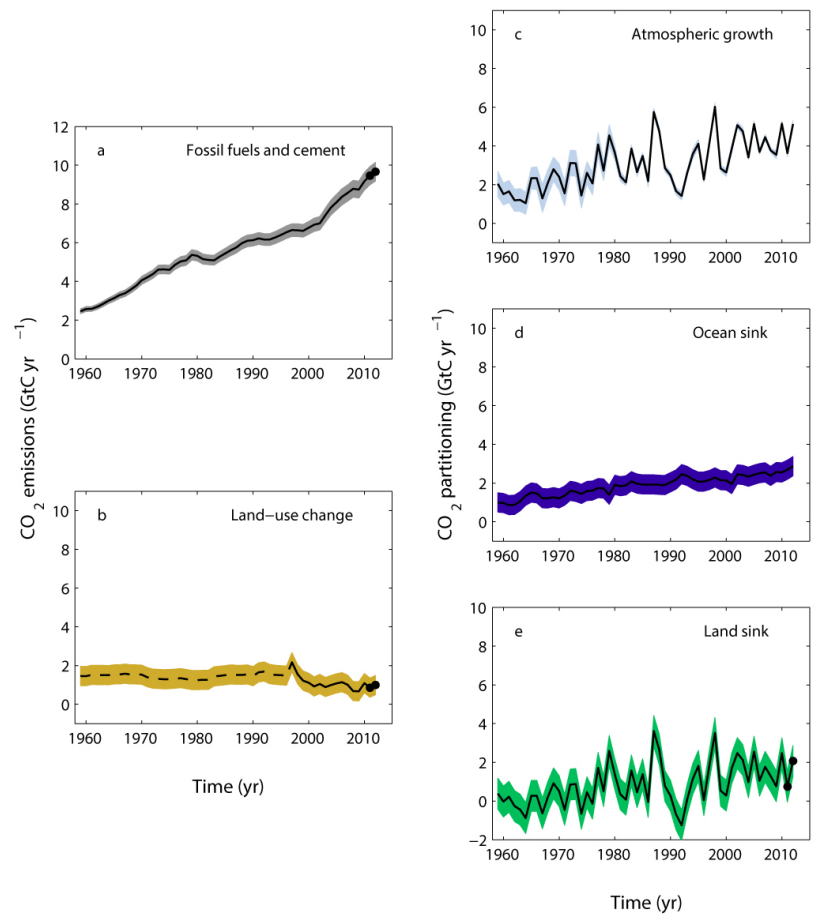

Figure 3. Components of the global carbon budget and their uncertainties as a function of time, presented individually for (a) emissions from fossil-fuel combustion and cement production $\left(E_{\mathrm{FF}}\right)$, (b) emissions from land-use change $\left(E_{\mathrm{LUC}}\right)$, (c) atmospheric $\mathrm{CO}_{2}$ growth rate $\left(G_{\mathrm{ATM}}\right)$, (d) the ocean $\mathrm{CO}_{2}$ sink $\left(S_{\text {OCEAN }}\right.$, positive indicates a flux from the atmosphere to the ocean), and (e) the land $\mathrm{CO}_{2}$ sink $\left(S_{\mathrm{LAND}}\right.$, positive indicates a flux from the atmosphere to the land). All time series are in $\mathrm{GtC} \mathrm{yr}^{-1}$ with the uncertainty bounds representing $\pm 1 \sigma$ in shaded colour. Data sources are as in Fig. 2. The black dots in (a), (b) and (e) show values for 2011 and 2012 that originate from a different data set to the remainder of the data, as explained in the text.

\subsection{Global carbon budget for year 2012 and emissions projection for 2013}

Global $\mathrm{CO}_{2}$ emissions from fossil-fuel combustion and cement production reached $9.7 \pm 0.5 \mathrm{GtC}$ in 2012 (Fig. 4), $2.2 \%$ higher than the emissions in 2011. This compares to our estimate of $2.6 \% \mathrm{yr}^{-1}$ made last year (Peters et al., 2013), based on an estimated GDP growth of $3.3 \% \mathrm{yr}^{-1}$ and improvement in $I_{\mathrm{FF}}$ of $-0.7 \% \mathrm{yr}^{-1}$ (Table 9). The latest estimate of GDP growth for 2012 was $3.2 \% \mathrm{yr}^{-1}$ (IMF, 2013) and hence $I_{\mathrm{FF}}$ improved $-1.0 \% \mathrm{yr}^{-1}$, slightly better than our prediction. The 2012 emissions were distributed among coal (43\%), oil (33\%), gas (18\%), cement (5.3\%) and gas flaring $(0.6 \%)$. These first four categories increased by $2.8 \%$, $1.2 \%, 2.5 \%$ and $2.5 \%$, respectively, over the previous year. Due to lack of data gas flaring in 2012 is assumed equal to 2011.

Using Eq. (6), we estimate that global fossil-fuel $\mathrm{CO}_{2}$ emissions in 2013 will reach $9.9 \pm 0.5 \mathrm{GtC}$, or $2.1 \%$ above

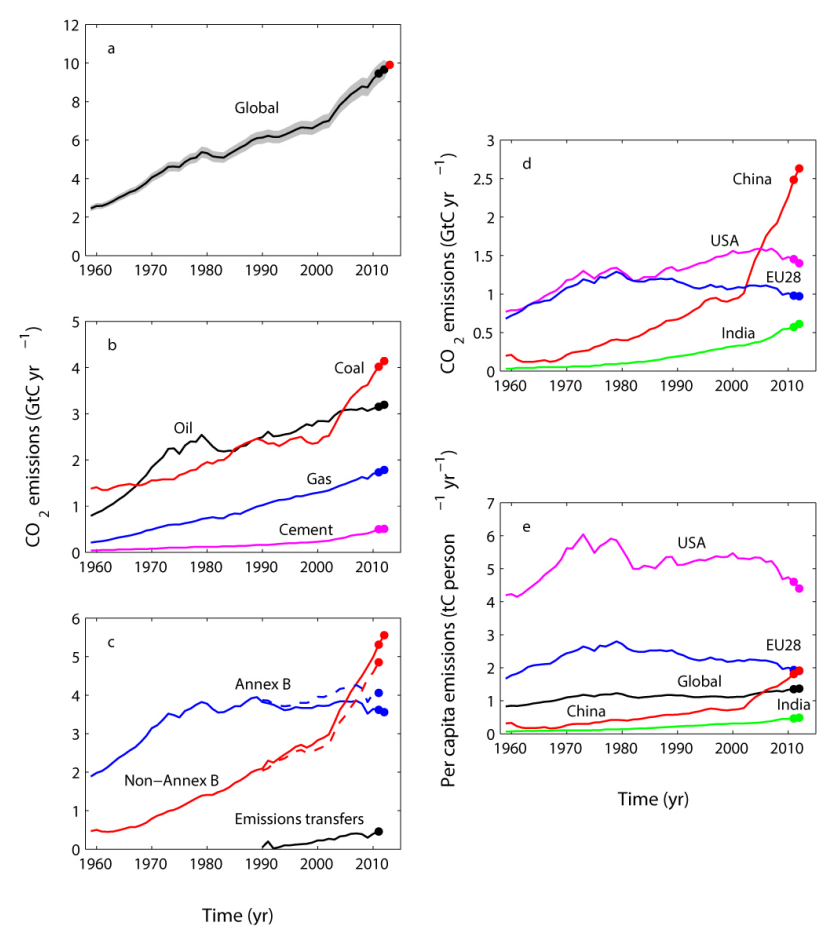

Figure 4. $\mathrm{CO}_{2}$ emissions from fossil-fuel combustion and cement production for (a) the globe, including an uncertainty of $\pm 5 \%$ (grey shading), the emissions extrapolated using BP energy statistics (black dots) and the emissions projection for year 2012 based on GDP projection (red dot), (b) global emissions by fuel type, including coal (red), oil (black), gas (blue), and cement (purple), and excluding gas flaring which is small $(0.7 \%$ in 2011), (c) territorial (full line) and consumption (dashed line) emissions for the countries listed in the Annex B of the Kyoto Protocol (blue lines; mostly advanced economies with emissions limitations) versus non-Annex B countries (red lines); also shown are the emissions transfer from non-Annex B to Annex B countries (black line), (d) territorial $\mathrm{CO}_{2}$ emissions for the top three country emitters (USA - purple; China red; India - green) and for the European Union (EU; blue for the 28 member states of the EU in 2012), and (e) per-capita emissions for the top three country emitters and the EU (all colours as in d) and the world (black). In (b-e), the dots show the data that were extrapolated from BP energy statistics for 2011 and 2012. All time series are in $\mathrm{GtC} \mathrm{yr}^{-1}$ except the per-capita emissions (e), which are in tonnes of carbon per person per year $\left(\mathrm{tC}_{\text {person }}{ }^{-1} \mathrm{yr}^{-1}\right)$. All territorial emissions are primarily from Boden et al. (2013) as detailed in the text; consumption-based emissions are updated from Peters et al. (2011a).

2012 levels (likely range of 1.1-3.1\%), and that emissions in 2013 will be $61 \%$ above emissions in 1990 . The expected value is computed using the world GDP projection of $2.9 \%$ made by the IMF (2013) and a growth rate for $I_{\mathrm{FF}}$ of $-0.8 \% \mathrm{yr}^{-1}$ which is the average from the previous 10 years. The $I_{\mathrm{FF}}$ is based on GDP in constant PPP (purchasing power parity) from the IEA (2012) up to 2010 (IEA/OECD, 2012) and extended using the IMF growth rates of $3.9 \%$ in 2011 and $3.2 \%$ in 2012 . The uncertainty range is based on an 
Table 9. Actual $\mathrm{CO}_{2}$ emissions from fossil-fuel combustion and cement production $\left(E_{\mathrm{FF}}\right)$ compared to projections made the previous year based on world GDP (IMF October 2013), and the fossil-fuel intensity of GDP $\left(I_{\mathrm{FF}}\right)$ based on subtracting the $\mathrm{CO}_{2}$ and GDP growth rates. The "Actual" values are the latest estimates available and the "Projected" values for 2013 refers to those presented in this paper.

\begin{tabular}{lrrrrrrrrr}
\hline Component & \multicolumn{2}{c}{$2009^{\mathrm{a}}$} & \multicolumn{2}{c}{$2010^{\mathrm{b}}$} & $2011^{\mathrm{c}}$ & $2012^{\mathrm{d}}$ & 2013 \\
\hline & Projected & Actual & Projected & Actual & Projected & Actual & Projected & Actual & Projected \\
\hline$E_{\mathrm{FF}}$ & $-2.8 \%$ & $-0.5 \%$ & $>3 \%$ & $4.9 \%$ & $3.1 \pm 1.5 \%$ & $3.2 \%$ & $2.6(1.9-3.5) \%$ & $2.2 \%$ & $2.1 \%$ \\
$\mathrm{GDP}$ & $-1.1 \%$ & $-0.4 \%$ & $4.8 \%$ & $5.2 \%$ & $4.0 \%$ & $3.9 \%$ & $3.3 \%$ & $3.2 \%$ & $2.9 \%$ \\
$I_{\mathrm{FF}}$ & $-1.7 \%$ & $-0.9 \%$ & $>-1.7 \%$ & $-0.3 \%$ & $-0.9 \pm 1.5 \%$ & $-0.7 \%$ & $-0.7 \%$ & $-1.0 \%$ & $-0.8 \%$ \\
\hline
\end{tabular}

${ }^{a}$ Le Quéré et al. (2009); ${ }^{b}$ Friedlingstein et al. (2010); ${ }^{\mathrm{c}}$ Peters et al. (2013); ${ }^{\mathrm{d}}$ Le Quéré et al. (2013).

uncertainty of $0.6 \%$ for GDP growth (the range in IMF estimates of 2013 GDP growth published in January, April, July, and October 2013 was $3.5 \%, 3.3 \%, 3.1 \%$ and $2.9 \%$, respectively) and the range in $I_{\mathrm{FF}}$ due to short-term trends of $-0.4 \% \mathrm{yr}^{-1}(2008-2012)$ and medium-term trends of $-1.2 \% \mathrm{yr}^{-1}$ (1990-2012). The combined uncertainty range is therefore $1.1 \%\left(2.9-0.6-1.2\right.$; low GDP growth, large $I_{\mathrm{FF}}$ improvements) and $3.1 \%$ (2.9+ 0.6-0.4; high GDP growth, small $I_{\mathrm{FF}}$ improvements). Projections made in the previous global carbon budgets compared well to the actual $\mathrm{CO}_{2}$ emissions for that year (Table 9 and Fig. 6) and were useful to capture the current state of the fossil-fuel emissions (see also Peters et al., 2013).

In 2012, global $\mathrm{CO}_{2}$ emissions were dominated by emissions from China (27\%), the USA (14\%), the EU (28 member states; $10 \%$ ), and India (6\%) compared to the global total including bunker fuels. These five regions account for $63 \%$ of global emissions. Growth rates for these countries from 2011 to 2012 were $5.9 \%$ (China), $-3.7 \%$ (USA), $-1.3 \%$ (EU28), and $7.7 \%$ (India). The countries contributing most to the 2012 change in emissions were China ( $71 \%$ increase), USA ( $26 \%$ decrease), India ( $21 \%$ increase), and Japan ( $11 \%$ increase). The per-capita $\mathrm{CO}_{2}$ emissions in 2012 were $1.4 \mathrm{tC}_{\text {person }}{ }^{-1} \mathrm{yr}^{-1}$ for the globe, and were 4.4 (USA), 1.9 (China), 1.9 (EU) and 0.5 (India) $\mathrm{tC}_{\text {person }}^{-1} \mathrm{yr}^{-1}$ (Fig. 4e).

Territorial-based emissions in Annex B countries remained stable from 1990 to 2011, while consumptionbased emissions grew at $0.5 \% \mathrm{yr}^{-1}$ (Fig. 4c). In nonAnnex B countries, territorial-based emissions have grown at $4.3 \% \mathrm{yr}^{-1}$, while consumption-based emissions have grown at $4.0 \% \mathrm{yr}^{-1}$. In 1990, $62 \%$ of global territorial-based emissions were emitted in Annex B countries (34\% in nonAnnex B, and $4 \%$ in bunker fuels used for international shipping and aviation), while in 2011 this had reduced to $38 \%$ (56\% in non-Annex B, and $6 \%$ in bunkers). In terms of consumption-based emissions, this split was $63 \%$ in 1990 and $43 \%$ in 2011 (33\% to $51 \%$ in non-Annex B). The difference between territorial-based and consumption-based emissions (the net emission transfer via international trade) from non-Annex B to Annex B countries has increased from $0.05 \mathrm{GtC} \mathrm{yr}^{-1}$ in 1990 to $0.46 \mathrm{GtC}$ in 2011 (Fig. 4), with an average annual growth rate of $12 \% \mathrm{yr}^{-1}$. The increase in net emission transfers of $0.41 \mathrm{GtC}$ from 1990 to 2011 compares with the emission reduction of $0.21 \mathrm{GtC}$ in Annex $B$ countries. These results clearly show a growing net emission transfer via international trade from non-Annex B to Annex B countries. In 2011, the biggest emitters from a consumption-based perspective were China (22\% of the global total), USA (17\%), EU28 (14\%), and India (5\%).

Based on DGVMs only, the global $\mathrm{CO}_{2}$ emissions from land-use change activities are estimated as $0.6 \pm 0.7 \mathrm{GtC}$ in 2012 , lower than the 2003-2012 average of $1.1 \pm 0.5 \mathrm{GtC} \mathrm{yr}^{-1}$. However, although the decadal mean generally agreed, the estimated annual variability was not consistent between the bookkeeping method and the DGVMs (Fig. 5a). This could be partly due to the design of the DGVM experiments, which use flux differences between simulations with and without land cover change, and thus may overestimate variability, for example, due to fires in forest regions where the contemporary forest cover is smaller than preindustrial cover used in the without land cover change runs. For this reason we assign a mean value to $E_{\mathrm{LUC}}$ for year 2012 based on the 2001-2010 average from the bookkeeping method.

The atmospheric $\mathrm{CO}_{2}$ growth rate was $5.1 \pm 0.2 \mathrm{GtC}$ in 2012 ( $2.41 \pm 0.09$ ppm; Fig. 3; Dlugokencky and Tans, 2013). This is significantly above the 2003-2012 average of $4.3 \pm 0.1 \mathrm{GtC} \mathrm{yr}^{-1}$, though the interannual variability in atmospheric growth rate is large.

The ocean $\mathrm{CO}_{2}$ sink was $2.9 \pm 0.5 \mathrm{GtC} \mathrm{yr}^{-1}$ in 2012 , an increase of $0.2 \mathrm{GtC} \mathrm{yr}^{-1}$ over 2011. This is larger than the 2003-2012 average of $2.5 \pm 0.5 \mathrm{GtC} \mathrm{yr}^{-1}$. All models produce an increase in the ocean $\mathrm{CO}_{2}$ sink in 2012 compared to 2011 except for MICOM-HAMOCC, which shows a very small decrease in the sink.

The terrestrial $\mathrm{CO}_{2}$ sink calculated as the residual from the carbon budget was $2.7 \pm 0.9 \mathrm{GtC}$ in 2012 , well below the $4.0 \pm 0.9 \mathrm{GtC}$ in 2011 , which was a La Niña year, but near the 2003-2012 average of $2.8 \pm 0.8 \mathrm{GtC} \mathrm{yr}^{-1}$ (Fig. 3). The DGVMs model mean suggests a lower terrestrial $\mathrm{CO}_{2}$ sink in 2012 of $1.8 \pm 1.1 \mathrm{GtC}$ (Table 7), possibly from weak El Niño conditions in the Northern Hemisphere spring of year 2012. 

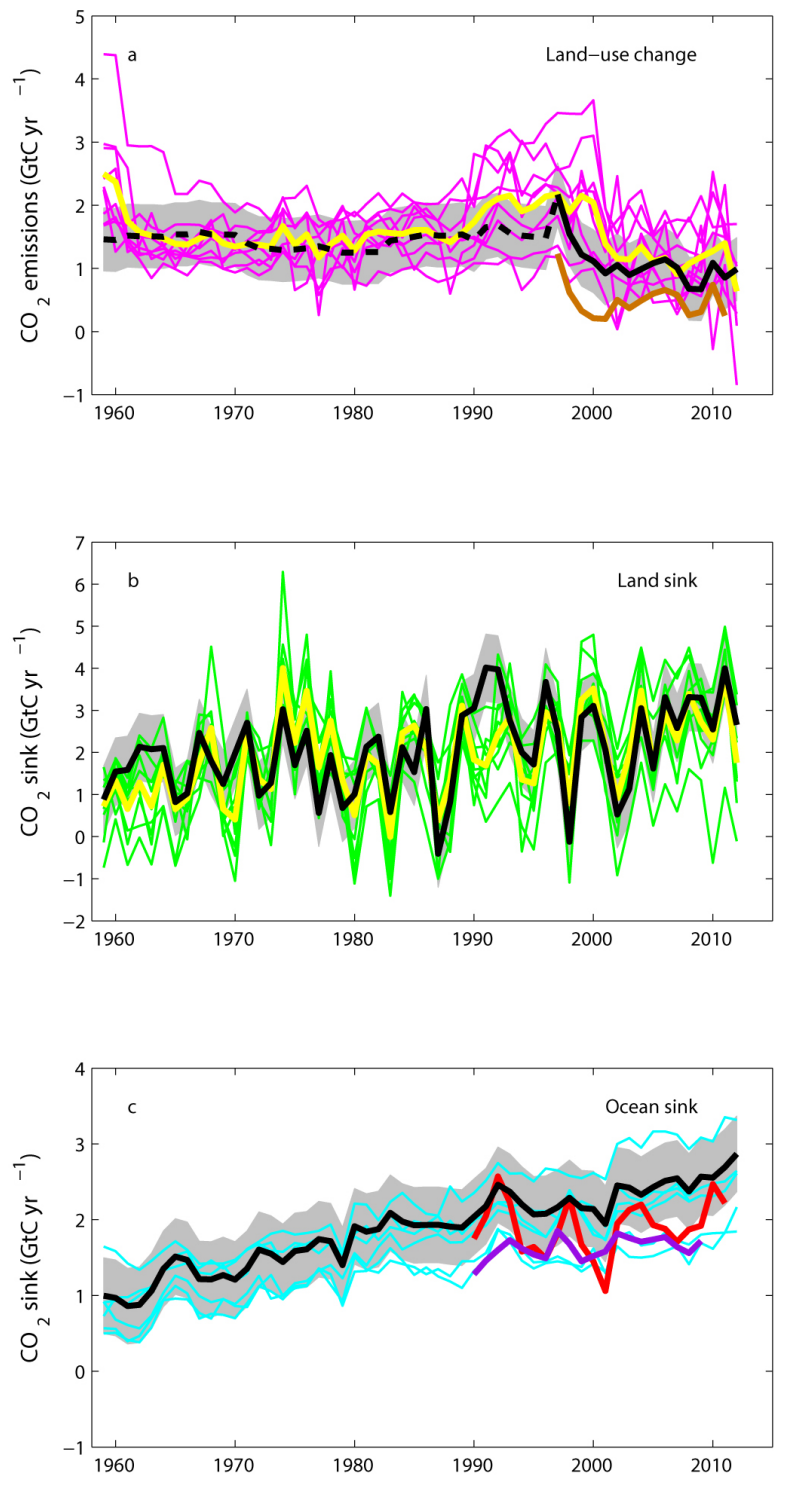

Time (yr)

Figure 5. Comparison between the $\mathrm{CO}_{2}$ budget values estimated here (black line), and other methods and models (Table 6; coloured lines) for (a) $\mathrm{CO}_{2}$ emissions from land-use change showing individual DGVM model results (magenta) and the multi model mean (yellow line), and fire-based results (orange), LUC data prior to 1997 (dashed black line) highlights the start of satellite data from that year (b) land $\mathrm{CO}_{2}$ sink $\left(S_{\mathrm{LAND}}\right)$ showing individual DGVM model results (green) and multi model mean (yellow line), and (c) ocean $\mathrm{CO}_{2}$ sink $\left(S_{\text {OCEAN }}\right)$ showing individual models before normalisation (blue lines), and the two data-based products (red line for Rödenbeck et al. (2014) and purple line for Park et al., 2010). Both data-based products were corrected for the preindustrial source of $\mathrm{CO}_{2}$ from riverine input to the ocean, which is not present in the models, by adding a sink of $0.45 \mathrm{GtC} \mathrm{yr}^{-1}$ (Jacobson et al., 2007), to make them comparable to SOCEAN .
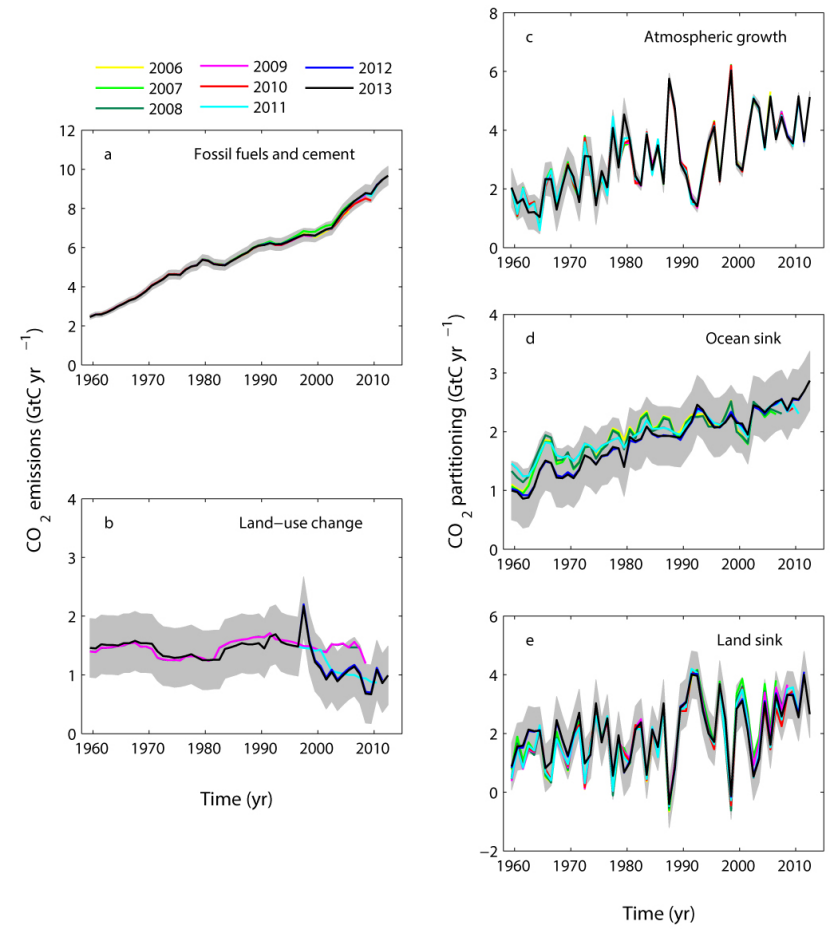

Figure 6. Comparison of global carbon budget components released annually by GCP since 2005. $\mathrm{CO}_{2}$ emissions from both (a) fossil-fuel combustion and cement production $\left(E_{\mathrm{FF}}\right)$, and (b) landuse change $\left(E_{\mathrm{LUC}}\right)$, and their partitioning among (c) the atmosphere $\left(G_{\text {ATM }}\right),(d)$ the ocean $\left(S_{\text {OCEAN }}\right)$, and $(e)$ the land $\left(S_{\text {LAND }}\right)$. See legend for the corresponding years, with the 2006 carbon budget from Raupach et al. (2007); 2007 from Canadell et al. (2007); to 2008 published online only; 2009 from Le Quéré et al. (2009); 2010 from Friedlingstein et al. (2010); 2011 from Peters et al. (2012b); 2012 from Le Quéré et al. (2013); and this year's budget (2013). The budget year generally corresponds to the year when the budget

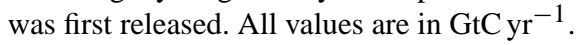

The DGVMs thus estimate internally consistent land fluxes over 2012, with both $E_{\mathrm{LUC}}$ and $S_{\mathrm{LAND}}$ being weaker than those of the carbon budget. Internal consistency is an emerging property of the models, not an a priori constraint as is the residual calculation of $S_{\text {LAND. }}$. These results thus suggest that constraints from DGVMs may provide sufficient information to be directly incorporated in the budget calculations in the future.

\subsection{Cumulative emissions}

Cumulative emissions for $1870-2012$ were $380 \pm 20 \mathrm{GtC}$ for $E_{\mathrm{FF}}$, and $145 \pm 55 \mathrm{GtC}$ for $E_{\mathrm{LUC}}$ based on the bookkeeping method of Houghton et al. (2012) for 1870-2010, with an extension to 2012 based on methods described in Sect. 2.2 (Table 10). The cumulative emissions are rounded to the nearest $5 \mathrm{GtC}$. The total cumulative emissions for 1870 2012 are $525 \pm 55 \mathrm{GtC}$. These emissions were partitioned among the atmosphere $(220 \pm 5 \mathrm{GtC})$ based on atmospheric 
measurements in ice cores of $288 \mathrm{ppm}$ (Sect. 2.3.1; Joos and Spahni, 2008) and recent direct measurements of $392.52 \mathrm{ppm}$ (Dlugokencky and Tans, 2013), ocean $(150 \pm 20 \mathrm{GtC}$ using Khatiwala et al. (2013) prior to 1959 and Table 8 otherwise), and the land ( $155 \pm 55 \mathrm{GtC}$ by difference).

Cumulative emissions for the early period 1750-1869 were $3 \mathrm{GtC}$ for $E_{\mathrm{FF}}$, and about $45 \mathrm{GtC}$ for $E_{\mathrm{LUC}}$, of which $15 \mathrm{GtC}$ were emitted in the period 1850-1870 (Houghton et al., 2012) and $30 \mathrm{GtC}$ were emitted in the period 1750-1850 based on the average of four publications ( $22 \mathrm{GtC}$ by Pongratz et al. (2009); $15 \mathrm{GtC}$ by van Minnen et al. (2009); $64 \mathrm{GtC}$ by Shevliakova et al. (2009) and $24 \mathrm{GtC}$ by Zaehle et al., 2011). The growth in atmospheric $\mathrm{CO}_{2}$ during that time was about $25 \mathrm{GtC}$, and the ocean uptake about $15 \mathrm{GtC}$, implying a land uptake of $10 \mathrm{GtC}$. These numbers have large relative uncertainties but balance within the limits of our understanding.

Cumulative emissions for 1750-2012 based on the sum of the two periods above were $385 \pm 20 \mathrm{GtC}$ for $E_{\mathrm{FF}}$, and $185 \pm 65 \mathrm{GtC}$ for $E_{\mathrm{LUC}}$, for a total of $570 \pm 70 \mathrm{GtC}$, partitioned among the atmosphere $(245 \pm 5 \mathrm{GtC})$, ocean $(165 \pm 20 \mathrm{GtC})$, and the land $(160 \pm 70 \mathrm{GtC})$.

Cumulative emissions through to year 2013 can be estimated based on the 2013 projections of $E_{\mathrm{FF}}$ (Sect. 3.2), the largest contributor, and assuming a constant $E_{\mathrm{LUC}}$. For 1870-2013, these are $535 \pm 55 \mathrm{GtC}$ for total emissions, with about $70 \%$ contribution from $E_{\mathrm{FF}}(390 \pm 20 \mathrm{GtC})$ and about $30 \%$ contribution from $E_{\mathrm{LUC}}(145 \pm 50 \mathrm{GtC})$. Cumulative emissions since year 1870 are higher than the emissions of 515 [445 to 585] GtC reported in the IPCC (Stocker et al., 2013b) because they include an additional $21 \mathrm{GtC}$ from emissions in 2012 and 2013 (mostly from $E_{\mathrm{FF}}$ ). The uncertainty presented here $( \pm 1 \sigma)$ is smaller than the range of $90 \%$ used by IPCC, but both estimates overlap within their uncertainty ranges.

\section{Discussion}

Each year when the global carbon budget is published, each component for all previous years is updated to take into account corrections that are due to further scrutiny and verification of the underlying data in the primary input data sets. The updates have generally been relatively small and focused on the most recent years, except for LUC, where they are more significant but still generally within the provided uncertainty range (Fig. 6). The difficulty in accessing land cover change data to estimate $E_{\mathrm{LUC}}$ is the key problem to providing continuous records of emissions in this sector. Revisions in $E_{\mathrm{LUC}}$ for the 2008/2009 budget were the result of the release of FAO 2010, which contained a major update to forest cover change for the period 2000-2005 and provided the data for the following 5 years to 2010 (Fig. 6b). The differences this year could be attributable to both the different data and the different methods. Updates were at most $0.24 \mathrm{GtC} \mathrm{yr}^{-1}$ for the fossil fuel and cement emissions, $0.19 \mathrm{GtC} \mathrm{yr}^{-1}$ for the atmospheric growth rate, $0.20 \mathrm{GtC} \mathrm{yr}^{-1}$ for the ocean $\mathrm{CO}_{2}$ sink, all within the reported uncertainty. The update for the residual land $\mathrm{CO}_{2}$ sink was also large (Fig. 6e), with a maximum value of $0.71 \mathrm{GtC} \mathrm{yr}^{-1}$, directly reflecting revisions in other terms of the budget, but still within the reported uncertainty.

Our capacity to separate the carbon budget components can be evaluated by comparing the land $\mathrm{CO}_{2}$ sink estimated with the budget residual $\left(S_{\text {LAND }}\right)$, which includes errors and biases from all components, with the land $\mathrm{CO}_{2}$ sink estimated by the DGVM ensemble, which are based on our understanding of processes of how the land responds to increasing $\mathrm{CO}_{2}$, climate change and variability. The two estimates are generally close (Fig. 5), both for the mean and for the interannual variability. The DGVM mean correlates with the budget residual with $r=0.71$ (Sect. 2.5.2; Fig. 5). The DGVMs produce a decadal mean and standard deviation across nine models of $2.5 \pm 0.8 \mathrm{GtC} \mathrm{yr}^{-1}$ for the period 2000-2009, nearly the same as the estimate produced with the budget residual (Table 7). Finally the fact that the DGVMs provide an internally consistent split between $E_{\mathrm{LUC}}$ and $S_{\text {LAND }}$ for year 2012 suggests that they could inform the annual budget analysis more extensively as the effort evolves. Analysis of regional carbon budgets would provide further information to quantify and improve our estimates, as has been undertaken by the Regional Carbon Cycle Assessment and Processes (Canadell et al., 2012-2013).

Annual estimates of each component of the global carbon budgets have their limitations, some of which could be improved with better data and/or better understanding of carbon dynamics. The primary limitations involve resolving fluxes on annual timescales and providing updated estimates for recent years for which data-based estimates are not yet available or only beginning to emerge. Of the various terms in the global budget, only the fossil-fuel burning and atmospheric growth rate terms are based primarily on empirical inputs supporting annual estimates in this carbon budget. The data on fossil-fuel consumption and cement production are based on survey data in all countries. The other terms can be provided on an annual basis only through the use of models. While these models represent the current state of the art, they provide only estimates of actual changes. For example, the decadal trends in ocean uptake and the interannual variations associated with El Niño/La Niña (ENSO) are not directly constrained by observations, although many of the processes controlling these trends are sufficiently well known that the model-based trends still have value as benchmarks for further validation. Data-based products for the ocean $\mathrm{CO}_{2}$ sink provide new ways to evaluate the model results, and could be used directly as data become more rapidly available and methods for creating such products improve. Estimates of land-use emissions and their year-to-year variability have even larger uncertainty, and much of the underlying data are not available as an annual update. Efforts are underway to 
Table 10. Cumulative $\mathrm{CO}_{2}$ emissions for the periods 1750-2012, 1870-2012 and 1870-2013 in GtC. All uncertainties are reported as $\pm 1 \sigma$. All values are rounded to nearest $5 \mathrm{GtC}$ as in Stocker et al. (2013b), reflecting the limits of our capacity to constrain cumulative estimates.

\begin{tabular}{lccc}
\hline & $1750-2012(\mathrm{GtC})$ & 1870-2012 $(\mathrm{GtC})$ & 1870-2013 $(\mathrm{GtC})$ \\
\hline Emissions & & & \\
\hline Fossil-fuel combustion and & $385 \pm 20$ & $380 \pm 20$ & $390 \pm 20^{*}$ \\
cement production $\left(E_{\mathrm{FF}}\right)$ & $185 \pm 65$ & $145 \pm 55$ & $145 \pm 50^{*}$ \\
Land-use change emissions $\left(E_{\mathrm{LUC}}\right)$ & $570 \pm 70$ & $525 \pm 55$ & $535 \pm 55^{*}$ \\
Total emissions & & & \\
\hline Partitioning & $245 \pm 5$ & $220 \pm 5$ & \\
\hline Atmospheric growth rate $\left(G_{\mathrm{ATM}}\right)$ & $165 \pm 20$ & $150 \pm 20$ & \\
Ocean sink $\left(S_{\text {OCEAN }}\right)$ & $160 \pm 70$ & $155 \pm 55$ & \\
Residual terrestrial sink $\left(S_{\text {LAND }}\right)$ & & & \\
\hline
\end{tabular}

* The extension to year 2013 uses the emissions projections for 2013 of $9.9 \mathrm{GtC}$ (Sect. 3.2) and assumes a constant $E_{\mathrm{LUC}}$ flux as in 2012 (Sect. 2.2)

work with annually available satellite area change data or FAO reported data in combination with fire data and modelling to provide annual updates for future budgets. The bestresolved changes are in atmospheric growth $\left(G_{\mathrm{ATM}}\right)$, fossilfuel emissions $\left(E_{\mathrm{FF}}\right)$, and by difference, the change in the sum of the remaining terms $\left(S_{\text {OCEAN }}+S_{\text {LAND }}-E_{\mathrm{LUC}}\right)$. The variations from year-to-year in these remaining terms are largely model-based at this time. Further efforts to increase the availability and use of annual data for estimating the remaining terms with annual to decadal resolution are especially needed.

Our approach also depends on the reliability of the energy and land-cover change statistics provided at the country level, and are thus potentially subject to biases. Thus it is critical to develop multiple ways to estimate the carbon balance at the global and regional level, including estimates from the inversion of atmospheric $\mathrm{CO}_{2}$ concentration, the use of other oceanic and atmospheric tracers, and the compilation of emissions using alternative statistics (e.g. sectors). Multiple approaches ranging from global to regional scale would greatly help increase confidence and reduce uncertainty in $\mathrm{CO}_{2}$ emissions and their fate.

\section{Conclusions}

The estimation of global $\mathrm{CO}_{2}$ emissions and sinks is a major effort by the carbon cycle research community that requires a combination of measurements and compilation of statistical estimates and results from models. The delivery of an annual carbon budget serves two purposes. First, there is a large demand for up-to-date information on the state of the anthropogenic perturbation of the climate system and its underpinning causes. A broad stakeholder community relies on the data sets associated with the annual carbon budget including scientists, policy makers, businesses, journalists, and the broader society increasingly engaged in adapting to and mit- igating human-driven climate change. Second, over the last decade we have seen unprecedented changes in the human and biophysical environments (e.g. increase in the growth of fossil-fuel emissions, ocean temperatures, and strength of the land sink), which call for more frequent assessments of the state of the planet, and by implications a better understanding of the future evolution of the carbon cycle, and the requirements for climate change mitigation and adaptation. Both the ocean and the land surface presently remove a large fraction of anthropogenic emissions. Any significant change in the function of carbon sinks is of great importance to climate policymaking, as they affect the excess carbon dioxide remaining in the atmosphere and therefore the compatible emissions for any climate stabilisation target. Better constraints of carbon cycle models against contemporary data sets raises the capacity for the models to become more accurate at future projections.

This all requires more frequent, robust, and transparent data sets and methods that can be scrutinised and replicated. After eight annual releases from the GCP, the effort is growing and the traceability of the methods has become increasingly complex. Here, we have documented in detail the data sets and methods used to compile the annual updates of the global carbon budget, explained the rationale for the choices made, the limitations of the information, and finally highlighted the need for additional information where gaps exist.

This paper, via "living data", will help to keep track of new budget updates. The evolution over time of the carbon budget is now a key indicator of the anthropogenic perturbation of the climate system, and its annual delivery joins a set of other climate indicators to monitor the evolution of humaninduced climate change, such as the annual updates on the global surface temperature, sea level rise, minimum Arctic sea ice extent and others. 


\section{Data access}

The data presented here is made available in the belief that their wide dissemination will lead to greater understanding and new scientific insights of how the carbon cycle works, how humans are altering it, and how we can mitigate the resulting human-driven climate change. The free availability of these data does not constitute permission for publication of the data. For research projects, if the data are essential to the work, or if an important result or conclusion depends on the data, co-authorship may need to be considered. Full contact details and information on how to cite the data are given at the top of each page in the accompanying database, and summarised in Table 2.

The accompanying database includes an Excel file organised in the following spreadsheets (accessible with the free viewer http://www.microsoft.com/en-us/download/ details.aspx id=10):

1. summary

2. the global carbon budget (1959-2012)

3. global $\mathrm{CO}_{2}$ emissions from fossil-fuel combustion and cement production by fuel type, and the per-capita emissions (1959-2012)

4. territorial-based (e.g. as reported to the UN Framework Convention on Climate Change) country $\mathrm{CO}_{2}$ emissions from fossil-fuel combustion and cement production (1959-2012)

5. consumption-based country $\mathrm{CO}_{2}$ emissions from fossilfuel combustion and cement production and emissions transfer from the international trade of goods and services (1990-2011)

6. emissions transfers (consumption minus territorial emissions; 1990-2011)

7. $\mathrm{CO}_{2}$ emissions from land-use change from the individual methods and models (1959-2012)

8. ocean $\mathrm{CO}_{2}$ sink from the individual ocean models (1959-2012)

9. terrestrial residual $\mathrm{CO}_{2}$ sink from the DGVMs (19592012)

10. additional information on the carbon balance prior to 1959 (1750-2012)

11. country definitions.

Acknowledgements. We thank all people and institutions that provided data used in this carbon budget, P. Cadule, C. Enright, J. Ghattas, and G. Hurtt for support to the model simulations,
F. Joos and S. Khatiwala for providing historical data, M. Heimann and G. McKinley for their comments and suggestions. The observations and modelling analysis were possible thanks to the generous support from the author's institutions and funding from multiple agencies around the world. We thank the many researchers and funding agencies responsible for the collection and quality control of the data included in SOCAT, and the support of the International Ocean Carbon Coordination Project (IOCCP), the Surface Ocean Lower Atmosphere Study (SOLAS), and the Integrated Marine Biogeochemistry and Ecosystem Research program (IMBER). The UK Natural Environment Research Council (NERC) provided funding to C. Le Quéré, R. Moriarty and the GCP though their International Opportunities Fund specifically to support this publication (project NE/103002X/1). R. J. Andres and T. A. Boden were supported by the US Department of Energy, Office of Science, Biological and Environmental Research (BER) programs under US Department of Energy contract DE-AC0500OR22725. G. P. Peters and R. M. Andrews were supported by the Norwegian Research Council (221355). A. Arneth, A. Omar, C. Le Quéré, J. Schwinger, P. Ciais, P. Friedlingstein, P. Regnier, J. Segschneider, S. Sitch and S. Zaehle were supported by the EU FP7 for funding through projects GEOCarbon (283080), COMBINE (226520), CARBOCHANGE (264879), EMBRACE (GA282672), and LUC4C (GA603542). A. Harper was supported by the NERC Joint Weather and Climate Research Programme. A. K. Jain was supported by the US National Science Foundation (NSF AGS 12-43071) the US Department of Energy, Office of Science and BER programs (DOE DE-SC0006706) and NASA LCLUC program (NASA NNX14AD94G). B. D. Stocker was supported by the Swiss National Science Foundation. A. Wiltshire was supported by the Joint UK DECC/Defra Met Office Hadley Centre Climate Programme (GA01101). E. Kato was supported by the Environment Research and Technology Development Fund (S-10) of the Ministry of Environment of Japan. J. G. Canadell and M. R. Raupach were supported by the Australian Climate Change Science Program. J. I. House was supported by a Leverhulme Research Fellowship. S. C. Doney was supported by the US National Science Foundation (NSF AGS-1048827).

Edited by: D. Carlson

\section{References}

Andres, R. J., Fielding, D. J., Marland, G., Boden, T. A., Kumar, N., and Kearney, A. T.: Carbon dioxide emissions from fossil fuel use, 1751-1950, Tellus, 51, 759-765, 1999.

Andres, R. J., Boden, T. A., Bréon, F.-M., Ciais, P., Davis, S., Erickson, D., Gregg, J. S., Jacobson, A., Marland, G., Miller, J., Oda, T., Olivier, J. G. J., Raupach, M. R., Rayner, P., and Treanton, K.: A synthesis of carbon dioxide emissions from fossil-fuel combustion, Biogeosciences, 9, 1845-1871, doi:10.5194/bg-9-18452012, 2012.

Andrew, R. M. and Peters, G. P.: A multi-region input-output table based on the Global Trade Analysis Project Database (GTAPMRIO), Economic Systems Research, 25, 99-121, 2013.

Archer, D., Eby, M., Brovkin, V., Ridgwell, A., Cao, L., Mikolajewicz, U., Caldeira, K. M., K., Munhoven, G., Montenegro, A., and Tokos, K.: Atmospheric Lifetime of Fossil Fuel Carbon Dioxide, Annu. Rev. Earth Pl. Sc., 37, 117-134, 2009. 
Assmann, K. M., Bentsen, M., Segschneider, J., and Heinze, C.: An isopycnic ocean carbon cycle model, Geosci. Model Dev., 3, 143-167, doi:10.5194/gmd-3-143-2010, 2010.

Atlas, R., Hoffman, R. N., Ardizzone, J., Leidner, S. M., Jusem, J. C., Smith, D. K., and Gombos, D.: A cross-calibrated, multiplatform ocean surface wind velocity product for meteorological and oceanographic applications, B. Amer. Meteorol. Soc., 92, 157174, 2011.

Aufdenkampe, A. K., Mayorga, E., Raymond, P. A., Melack, J. M., Doney, S. C., Alin, S. R., Aalto, R. E., and Yoo, K.: Riverine coupling of biogeochemical cycles between land, oceans and atmosphere, Frontiers Ecology Environ., 9, 53-60, 2011.

Aumont, O. and Bopp, L.: Globalizing results from ocean in situ iron fertilization studies, Global Biogeochem. Cy., 20, GB2017, doi:10.1029/2005GB002591, 2006.

Baccini, A., Goetz, S. J., Walker, W. S., Laporte, N. T., Sun, M., Sulla-Menashe, D., Hackler, J., Beck, P. S. A., Dubayah, R., Friedl, M. A., Samanta, S., and Houghton, R. A.: Estimated carbon dioxide emissions from tropical deforestation improved by carbon-density maps, Nature Clim. Change, 2, 182-186, 2012.

Bakker, D. C. E., Pfeil, B., Smith, K., Hankin, S., Olsen, A., Alin, S. R., Cosca, C., Harasawa, S., Kozyr, A., Nojiri, Y., O’Brien, K. M., Schuster, U., Telszewski, M., Tilbrook, B., Wada, C., Akl, J., Barbero, L., Bates, N. R., Boutin, J., Bozec, Y., Cai, W.-J., Castle, R. D., Chavez, F. P., Chen, L., Chierici, M., Currie, K., de Baar, H. J. W., Evans, W., Feely, R. A., Fransson, A., Gao, Z., Hales, B., Hardman-Mountford, N. J., Hoppema, M., Huang, W.-J., Hunt, C. W., Huss, B., Ichikawa, T., Johannessen, T., Jones, E. M., Jones, S. D., Jutterström, S., Kitidis, V., Körtzinger, A., Landschützer, P., Lauvset, S. K., Lefèvre, N., Manke, A. B., Mathis, J. T., Merlivat, L., Metzl, N., Murata, A., Newberger, T., Omar, A. M., Ono, T., Park, G.-H., Paterson, K., Pierrot, D., Ríos, A. F., Sabine, C. L., Saito, S., Salisbury, J., Sarma, V. V. S. S., Schlitzer, R., Sieger, R., Skjelvan, I., Steinhoff, T., Sullivan, K. F., Sun, H., Sutton, A. J., Suzuki, T., Sweeney, C., Takahashi, T., Tjiputra, J., Tsurushima, N., van Heuven, S. M. A. C., Vandemark, D., Vlahos, P., Wallace, D. W. R., Wanninkhof, R., and Watson, A. J.: An update to the Surface Ocean $\mathrm{CO}_{2}$ Atlas (SOCAT version 2), Earth Syst. Sci. Data, 6, 69-90, doi:10.5194/essd-6-69-2014, 2014.

Ballantyne, A. P., Alden, C. B., Miller, J. B., Tans, P. P., and White, J. W. C.: Increase in observed net carbon dioxide uptake by land and oceans during the last 50 years, Nature, 488, 70-72, 2012.

Bastviken, D., Tranvik, L. J., Downing, J. A., Crill, P. M., and Enrich-Prast, A.: Freshwater methane emissions offset the continental carbon sink, Science, 331, 6013, doi:10.1126/science.1196808, 2011.

Battin, T. J., Luyssaert, S., Kaplan, L. A., Aufdenkampe, A. K., Richter, A., and Tranvik, L. J.: The boundless carbon cycle, Nat. Geosci., 2, 598-600, 2009.

Best, M. J., Pryor, M., Clark, D. B., Rooney, G. G., Essery, R .L. H., Ménard, C. B., Edwards, J. M., Hendry, M. A., Porson, A., Gedney, N., Mercado, L. M., Sitch, S., Blyth, E., Boucher, O., Cox, P. M., Grimmond, C. S. B., and Harding, R. J.: The Joint UK Land Environment Simulator (JULES), model description Part 1: Energy and water fluxes, Geosci. Model Dev., 4, 677-699, doi:10.5194/gmd-4-677-2011, 2011.

Boden, T. A., Marland, G., and Andres, R. J.: Global, Regional, and National Fossil-Fuel $\mathrm{CO}_{2}$ Emissions, Oak Ridge National
Laboratory, US Department of Energy, Oak Ridge, Tenn., USA, 2013.

Borges, A. V. and Abril, G.: Carbon dioxide and methane dynamics in estuaries, in: Treatise on Estuarine and Coastal Science, edited by: Wolanski, E. and McLusky, D. S., Academic Press, 2011.

BP: $\quad$ http://www.bp.com/en/global/corporate/about-bp/ statistical-review-of-world-energy-2013.html (last access: August 2013), 2013.

Bruno, M. and Joos, F.: Terrestrial carbon storage during the past 200 years: A monte carlo analysis of $\mathrm{CO}_{2}$ data from ice core and atmospheric measurements, Global Biogeochem. Cy., 11, 111124, 1997.

Buitenhuis, E. T., Rivkin, R. B., Sailley, S., and Le Quéré, C.: Biogeochemical fluxes through microzooplankton, Global Biogeochem. Cy., 24, GB4015, doi:10.1029/2009GB003601, 2010.

Canadell, J. G., Le Quéré, C., Raupach, M. R., Field, C. B., Buitenhuis, E. T., Ciais, P., Conway, T. J., Gillett, N. P., Houghton, R. A., and Marland, G.: Contributions to accelerating atmospheric $\mathrm{CO}_{2}$ growth from economic activity, carbon intensity, and efficiency of natural sinks, P. Natl. Acad. Sci. USA, 104, 1886618870, 2007.

Canadell, J. G., Ciais, P., Sabine, C., and Joos, F. (Eds.): REgional Carbon Cycle Assessment and Processes (RECCAP), http:// www.biogeosciences.net/special_issue107.html, 2012-2013.

Ciais, P., Sabine, C., Govindasamy, B., Bopp, L., Brovkin, V., Canadell, J., Chhabra, A., DeFries, R., Galloway, J., Heimann, M., Jones, C., Le Quéré, C., Myneni, R., Piao, S., and Thornton, P.: Chapter 6: Carbon and Other Biogeochemical Cycles, in: Climate Change 2013 The Physical Science Basis, edited by: Stocker, T., Qin, D., and Platner, G.-K., Cambridge University Press, Cambridge, 2013.

Clark, D. B., Mercado, L. M., Sitch, S., Jones, C. D., Gedney, N., Best, M. J., Pryor, M., Rooney, G. G., Essery, R. L. H., Blyth, E., Boucher, O., Harding, R. J., Huntingford, C., and Cox, P. M.: The Joint UK Land Environment Simulator (JULES), model description - Part 2: Carbon fluxes and vegetation dynamics, Geosci. Model Dev., 4, 701-722, doi:10.5194/gmd-4-701-2011, 2011.

Cole, J. J., Prairie, Y. T., Caraco, N. F., McDowell, W. H., Tranvik, L. J., Striegl, R. G., Duarte, C. M., Kortelainen, P., Downing, J. A., Middelburg, J. J., and Melack, J.: Plumbing the global carbon cycle: Integrating inland waters into the terrestrial carbon budget, Ecosystems, 10, 171-184, 2007.

Collins, W. J., Bellouin, N., Doutriaux-Boucher, M., Gedney, N., Halloran, P., Hinton, T., Hughes, J., Jones, C. D., Joshi, M., Liddicoat, S., Martin, G., O’Connor, F., Rae, J., Senior, C., Sitch, S., Totterdell, I., Wiltshire, A., and Woodward, S.: Development and evaluation of an Earth-System model - HadGEM2, Geosci. Model Dev., 4, 1051-1075, doi:10.5194/gmd-4-10512011, 2011.

Cox, P. M., Betts, R. A., Jones, C. D., Spall, S. A., and Totterdell, I. J.: Acceleration of global warming due to carbon-cycle feedbacks in a coupled climate model, Nature, 408, 184-187, 2000.

Davis, S. J. and Caldeira, K.: Consumption-based accounting of $\mathrm{CO}_{2}$ emissions, P. Natl. Acad. Sci., 107, 5687-5692, 2010.

Davis, S. J., Peters, G. P., and Caldeira, K.: The supply chain of $\mathrm{CO}_{2}$ emissions, P. Natl. Acad. Sci., 108, 18554-18559, 2011.

Denman, K. L., Brasseur, G., Chidthaisong, A., Ciais, P., Cox, P. M., Dickinson, R. E., Hauglustaine, D., Heinze, C., Holland, E., Jacob, D., Lohmann, U., Ramachandran, S., Leite da Silva Dias, 
P., Wofsy, S. C., and Zhang, X.: Couplings Between Changes in the Climate System and Biogeochemistry, Intergovernmental Panel on Climate Change, 499-587, 2007.

Dlugokencky, E. and Tans, P.: http://www.esrl.noaa.gov/gmd/ccgg/ trends, last access: 8 October 2013.

Doney, S. C., Lima, I., Feely, R. A., Glover, D. M., Lindsay, K., Mahowald, N., Moore, J. K., and Wanninkhof, R.: Mechanisms governing interannual variability in upper-ocean inorganic carbon system and air-sea $\mathrm{CO}_{2}$ fluxes: Physical climate and atmospheric dust, Deep-Sea Res. Pt. II, 56, 640-655, 2009.

Durant, A. J., Le Quéré, C., Hope, C., and Friend, A. D.: Economic value of improved quantification in global sources and sinks of carbon dioxide, Philols T. R. Soc. A, 269, 1967-1979, 2010.

Earles, J. M., Yeh, S., and Skog, K. E.: Timing of carbon emissions from global forest clearance, Nature Climate Change, 2, 682685, 2012.

El-Masri, B., Barman, R., Meiyappan, P., Song, Y., Liang, M., and Jain, A. K.: Carbon dynamics in the Amazonian Basin: Integration of eddy covariance and ecophysiological data with a land surface model, Agr. Forest Meteorol., 182-183, 156-167, 2013.

Erb, K.-H., Kastner, T., Luyssaert, S., Houghton, R. A., Kuemmerle, T., Olofsson, P., and Haberl, H.: Bias in the attribution of forest carbon sinks, Nature Climate Change, 3, 854-856, 2013.

Etheridge, D. M., Steele, L. P., Langenfelds, R. L., and Francey, R. J.: Natural and anthropogenic changes in atmospheric $\mathrm{CO}_{2}$ over the last 1000 years from air in Antarctic ice and firn, J. Geophys. Res., 101, 4115-4128, 1996.

FAO: Global Forest Resource Assessment 2010, 378 pp., 2010.

FAOSTAT: http://faostat.fao.org/2010, 2010.

Friedlingstein, P., Houghton, R. A., Marland, G., Hackler, J., Boden, T. A., Conway, T. J., Canadell, J. G., Raupach, M. R., Ciais, P., and Le Quéré, C.: Update on $\mathrm{CO}_{2}$ emissions, Nat. Geosci., 3, 811-812, 2010.

Galbraith, E. D., Gnanadesikan, A., Dunne, J. P., and Hiscock, M. R.: Regional impacts of iron-light colimitation in a global biogeochemical model, Biogeosciences, 7, 1043-1064, doi:10.5194/bg-7-1043-2010, 2010.

Gasser, T. and Ciais, P.: A theoretical framework for the net landto-atmosphere $\mathrm{CO}_{2}$ flux and its implications in the definition of "emissions from land-use change", Earth Syst. Dynam., 4, 171186, doi:10.5194/esd-4-171-2013, 2013.

GCP: http://lgmacweb.env.uea.ac.uk/lequere/co2/2007/carbon_ budget_2007.htm (last access: November 2013), 2013.

Giglio, L., Randerson, J. T., van der Werf, G. R., Kasibhatla, P. S., Collatz, G. J., Morton, D. C., and DeFries, R. S.: Assessing variability and long-term trends in burned area by merging multiple satellite fire products, Biogeosciences, 7, 1171-1186, doi:10.5194/bg-7-1171-2010, 2010.

Gitz, V. and Ciais, P.: Amplifying effects of land-use change on future atmospheric $\mathrm{CO}_{2}$ levels, Global Biogeochem. Cy., 17, 1024, doi:10.1029/2002GB001963, 2003.

Gregg, J. S., Andres, R. J., and Marland, G.: China: Emissions pattern of the world leader in $\mathrm{CO}_{2}$ emissions from fossil fuel consumption and cement production, Geophys. Res. Lett., 35, L08806, doi:10.1029/2007GL032887, 2008.

Harris, I., Jones, P. D., Osborn, T. J., and Lister, D. H.: Updated high-resolution grids of monthly climatic observations - the CRU TS3.10 Dataset, Int. J. Climatol., 1097-0088, doi:10.1002/joc.3711, 2013.
Hertwich, E. G. and Peters, G. P.: Carbon Footprint of Nations: A Global, Trade-Linked Analysis, Environ. Sci. Technol., 43, 6414-6420, 2009.

Houghton, R. A.: Revised estimates of the annual net flux of carbon to the atmosphere from changes in land use and land management 1850-2000, Tellus B, 55, 378-390, 2003.

Houghton, R. A., House, J. I., Pongratz, J., van der Werf, G. R., DeFries, R. S., Hansen, M. C., Le Quéré, C., and Ramankutty, N.: Carbon emissions from land use and land-cover change, Biogeosciences, 9, 5125-5142, doi:10.5194/bg-9-5125-2012, 2012.

Hurtt, G. C., Chini, L. P., Frolking, S., Betts, R. A., Feddema, J., Fischer, G., Fisk, J. P., Hibbard, K., Houghton, R. A., Janetos, A., Jones, C. D., Kindermann, G., Kinoshita, T., Klein Goldewijk, K., Riahi, K., Shevliakova, E., Smith, S., Stehfest, E., Thomson, A., Thornton, P., van Vuuren, D. P., and Wang, Y. P.: Harmonization of land-use scenarios for the period 1500-2100: 600 years of global gridded annual land-use transitions, wood harvest, and resulting secondary lands, Clim. Change, 109, 117-161, 2011.

IEA/OECD: $\mathrm{CO}_{2}$ emissions from fuel combustion, Paris, 2012.

Ilyina, T., Six, K., Segschneider, J., Maier-Reimer, E., Li, H., and Núñez-Riboni, I.: The global ocean biogeochemistry model HAMOCC: Model architecture and performance as component of the MPI-Earth System Model in different CMIP5 experimental realizations, Journal of Advances in Modeling Earth Systems, 5, 287-315, doi:10.1002/jame.20017, 2013.

IMF: http://www.imf.org/external/ns/cs.aspx?id=29, last access: 10 October 2013.

Ito, A. and Inatomi, M.: Use of a process-based model for assessing the methane budgets of global terrestrial ecosystems and evaluation of uncertainty, Biogeosciences, 9, 759-773, doi:10.5194/bg9-759-2012, 2012.

Jacobson, A. R., Mikaloff Fletcher, S. E., Gruber, N., Sarmiento, J. L., and Gloor, M.: A joint atmosphere-ocean inversion for surface fluxes of carbon dioxide: 1. Methods and global-scale fluxes, Global Biogeochem. Cy., 21, GB1019, doi:10.1029/2005GB002556, 2007.

Jain, A. K., Meiyappan, P., Song, Y., and House, J. I.: $\mathrm{CO}_{2}$ Emissions from Land-Use Change Affected More by Nitrogen Cycle, than by the Choice of Land Cover Data, Glob. Change Biol., 9, 2893-2906, doi:10.1111/gcb.12207, 2013.

Joos, F. and Spahni, R.: Rates of change in natural and anthropogenic radiative forcing over the past 20,000 years, P. Natl. Acad. Sci. USA, 105, 1425-1430, 2008.

Jung, M., Henkel, K., Herold, M., and Churkina, G.: Exploiting synergies of global land cover products for carbon cycle modeling, Remote Sens. Environ., 101, 534-553, 2006.

Kato, E., Kinoshita, T., Ito, A., Kawamiya, M., and Yamagata, Y.: Evaluation of spatially explicit emission scenario of land-use change and biomass burning using a process-based biogeochemical model, Journal of Land Use Science, 8, 104-122, 2013.

Keeling, C. D., Bacastow, R. B., Bainbridge, A. E., Ekdhal, C. A., Guenther, P. R., and Waterman, L. S.: Atmospheric carbon dioxide variations at Mauna Loa Observatory, Hawaii, Tellus, 28, 538-551, 1976.

Khatiwala, S., Primeau, F., and Hall, T.: Reconstruction of the history of anthropogenic $\mathrm{CO}_{2}$ concentrations in the ocean, Nature, 462, 346-350, 2009.

Khatiwala, S., Tanhua, T., Mikaloff Fletcher, S., Gerber, M., Doney, S. C., Graven, H. D., Gruber, N., McKinley, G. A., 
Murata, A., Ríos, A. F., and Sabine, C. L.: Global ocean storage of anthropogenic carbon, Biogeosciences, 10, 2169-2191, doi:10.5194/bg-10-2169-2013, 2013.

Kirschke, S., Bousquet, P., Ciais, P., Saunois, M., Canadell, J. G., Dlugokencky, E. J., Bergamaschi, P., Bergmann, D., Blake, D. R., Bruhwiler, L., Cameron Smith, P., Castaldi, S., Chevallier, F., Feng, L., Fraser, A., Heimann, M., Hodson, E. L., Houweling, S., Josse, B., Fraser, P. J., Krummel, P. B., Lamarque, J., Langenfelds, R. L., Le Quéré, C., Naik, V., O’Doherty, S., Palmer, P. I., Pison, I., Plummer, D., Poulter, B., Prinn, R. G., Rigby, M., Ringeval, B., Santini, M., Schmidt, M., Shindell, D. T., Simpson, I. J., Spahni, R., Steele, L. P., Strode, S. A., Sudo, K., Szopa, S., van der Werf, G. R., Voulgarakis, A., van Weele, M., Weiss, R. F., Williams, J. E., and Zeng, G.: Three decades of global methane sources and sinks, Nat. Geosci., 6, 813-823, doi:10.1038/ngeo1955, 2013.

Klein Goldewijk, K., Beusen, A., van Drecht, G., and de Vos, M.: The HYDE 3.1 spatially explicit database of human-induced global land-use change over the past 12,000 years, Global Ecol. Biogeogr., 20, 73-86, 2011.

Koven, C. D., Riley, W. J., Subin, Z. M., Tang, J. Y., Torn, M. S., Collins, W. D., Bonan, G. B., Lawrence, D. M., and Swenson, S. C.: The effect of vertically-resolved soil biogeochemistry and alternate soil $\mathrm{C}$ and $\mathrm{N}$ models on C dynamics of CLM4, Biogeosciences Discuss., 10, 7201-7256, doi:10.5194/bgd-10-72012013, 2013.

Krinner, G., Viovy, N., de Noblet, N., Ogée, J., Friedlingstein, P., Ciais, P., Sitch, S., Polcher, J., and Prentice, I. C.: A dynamic global vegetation model for studies of the coupled atmospherebiosphere system, Global Biogeochem. Cy., 19, 1-33, 2005.

Krumins, V., Gehlen, M., Arndt, S., Van Cappellen, P., and Regnier, P.: Dissolved inorganic carbon and alkalinity fluxes from coastal marine sediments: model estimates for different shelf environments and sensitivity to global change, Biogeosciences, 10, 371-398, doi:10.5194/bg-10-371-2013, 2013.

Lamarque, J.-F., Bond, T. C., Eyring, V., Granier, C., Heil, A., Klimont, Z., Lee, D., Liousse, C., Mieville, A., Owen, B., Schultz, M. G., Shindell, D., Smith, S. J., Stehfest, E., Van Aardenne, J., Cooper, O. R., Kainuma, M., Mahowald, N., McConnell, J. R., Naik, V., Riahi, K., and van Vuuren, D. P.: Historical (1850-2000) gridded anthropogenic and biomass burning emissions of reactive gases and aerosols: methodology and application, Atmos. Chem. Phys., 10, 7017-7039, doi:10.5194/acp10-7017-2010, 2010.

Laruelle, G. G., Durr, H. H., Slomp, C. P., and Borges, A. $\mathrm{V}$.: Evaluation of sinks and sources of $\mathrm{CO}_{2}$ in the global coastal ocean using a spatially-explicit typology of estuaries and continental shelves, Geophys. Res. Lett., 37, LI5607, doi:10.1029/2010GL043691, 2010.

Le Quéré, C.: Closing the global budget for $\mathrm{CO}_{2}$, Global Change, 74, 28-31, 2009.

Le Quéré, C., Raupach, M. R., Canadell, J. G., Marland, G., Bopp, L., Ciais, P., Conway, T. J., Doney, S. C., Feely, R. A., Foster, P., Friedlingstein, P., Gurney, K., Houghton, R. A., House, J. I., Huntingford, C., Levy, P. E., Lomas, M. R., Majkut, J., Metzl, N., Ometto, J. P., Peters, G. P., Prentice, I. C., Randerson, J. T., Running, S. W., Sarmiento, J. L., Schuster, U., Sitch, S., Takahashi, T., Viovy, N., van der Werf, G. R., and Woodward, F. I.:
Trends in the sources and sinks of carbon dioxide, Nat. Geosci., 2, 831-836, 2009.

Le Quéré, C., Andres, R. J., Boden, T., Conway, T., Houghton, R. A., House, J. I., Marland, G., Peters, G. P., van der Werf, G. R., Ahlström, A., Andrew, R. M., Bopp, L., Canadell, J. G., Ciais, P., Doney, S. C., Enright, C., Friedlingstein, P., Huntingford, C., Jain, A. K., Jourdain, C., Kato, E., Keeling, R. F., Klein Goldewijk, K., Levis, S., Levy, P., Lomas, M., Poulter, B., Raupach, M. R., Schwinger, J., Sitch, S., Stocker, B. D., Viovy, N., Zaehle, S., and Zeng, N.: The global carbon budget 1959-2011, Earth Syst. Sci. Data, 5, 165-185, doi:10.5194/essd-5-165-2013, 2013.

Manning, A. C. and Keeling, R. F.: Global oceanic and land biotic carbon sinks from the Scripps atmospheric oxygen flask sampling network, Tellus B, 58, 95-116, 2006.

Marland, G.: Uncertainties in accounting for $\mathrm{CO}_{2}$ from fossil fuels, J. Ind. Ecol., 12, 136-139, 2008.

Marland, G., Andres, R. J., Blasing, T. J., Boden, T. A., Broniak, C. T., Gregg, J. S., Losey, L. M., and Treanton, K.: Energy, industry and waste management activities: An introduction to $\mathrm{CO}_{2}$ emissions from fossil fuels. In: A report by the US Climate Change Science Program and the Subcommittee on Global Change Research, in The First State of the Carbon Cycle Report (SOCCR): The North American Carbon Budget and Implications for the Global Carbon Cycle, edited by: King, A. W., Dilling, L., Zimmerman, G. P., Fairman, D. M., Houghton, R. A., Marland, G., Rose, A. Z., and Wilbanks, T. J., Asheville, NC, 2007.

Marland, G., Hamal, K., and Jonas, M.: How Uncertain Are Estimates of $\mathrm{CO}_{2}$ Emissions?, J. Ind. Ecol., 13, 4-7, 2009.

Masarie, K. A. and Tans, P. P.: Extension and integratino of atmospheric carbon dioxide data into a globally consistent measurement record, J. Geophys. Res.-Atmos., 100, 11593-11610, 1995.

Masson-Delmotte, V., M. Schulz, A. Abe-Ouchi, J. Beer, A. Ganopolski, J.F. González Rouco, E. Jansen, K. Lambeck, J. Luterbacher, T. Naish, T. Osborn, B. Otto-Bliesner, T. Quinn, R. Ramesh, M. Rojas, X. Shao, and A. Timmermann: Information from Paleoclimate Archives. In: Climate Change 2013: The Physical Science Basis. Contribution of Working Group I to the Fifth Assessment Report of the Intergovernmental Panel on Climate Change, edited by: Stocker, T. F., D. Qin, G.-K. Plattner, M. Tignor, S.K. Allen, J. Boschung, A. Nauels, Y. Xia, Bex, V., and Midgley, P. M., Cambridge University Press, Cambridge, United Kingdom and New York, NY, USA, 2013.

McNeil, B. I., Matear, R. J., Key, R. M., Bullister, J. L., and Sarmiento, J. L.: Anthropogenic $\mathrm{CO}_{2}$ uptake by the ocean based on the global chlorofluorocarbon data set, Science, 299, 235239, 2003.

Mikaloff Fletcher, S. E., Gruber, N., Jacobson, A. R., Doney, S. C., Dutkiewicz, S., Gerber, M., Follows, M., Joos, F., Lindsay, K., Menemenlis, D., Mouchet, A., Müller, S. A., and Sarmiento, J. L.: Inverse estimates of anthropogenic $\mathrm{CO}_{2}$ uptake, transport, and storage by the oceans, Global Biogeochem. Cy., 20, GB2002, doi:10.1029/2005GB002530, 2006.

Narayanan, B., Aguiar, A., and McDougall, R.: http://www. gtap.agecon.purdue.edu/databases/v8/default.asp, last access: Septemper 2013.

NOAA/ESRL: http://www.esrl.noaa.gov/gmd/ccgg/about/global_ means.html, last access: August 2013.

Oleson, K., Lawrence, D., Bonan, G., Drewniak, B., Huang, M., Koven, C., Levis, S., Li, F., Riley, W., Subin, Z., Swenson, S., 
Thornton, P., Bozbiyik, A., Fisher, R., Heald, C., Kluzek, E., Lamarque, J., Lawrence, P., Leung, L., Lipscomb, W., Muszala, S., Ricciuto, D., Sacks, W., Tang, J., and Yang, Z.: Technical Description of version 4.5 of the Community Land Model (CLM), Technical Note \#NCAR/TN-503+STR, 2013.

Park, G. H., Wanninkhof, R., Doney, S. C., Takahashi, T., Lee, K., Feely, R. A., Sabine, C. L., Trinanes, J., and Lima, I. D.: Variability of global net sea-air $\mathrm{CO}_{2}$ fluxes over the last three decChemical and Physical Meteorology, 62, 352-368, 2010.

Peters, G. P. and Hertwich, E. G.: Post-Kyoto Greenhouse Gas Inventories: Production versus Consumption, Clim. Change, 86, 51-66, 2008.

Peters, G. P., Andrew, R., and Lennos, J.: Constructing a multiregional input-output table using the GTAP database, Economic Systems Research, 23, 131-152, 2011a.

Peters, G. P., Minx, J. C., Weber, C. L., and Edenhofer, O.: Growth in emission transfers via international trade from 1990 to 2008, P. Natl. Acad. Sci. USA, 108, 8903-8908, 2011 b.

Peters, G. P., Davis, S. J., and Andrew, R.: A synthesis of carbon in international trade, Biogeosciences, 9, 3247-3276, doi:10.5194/bg-9-3247-2012, 2012a.

Peters, G. P., Marland, G., Le Quéré, C., Boden, T. A., Canadell, J. G., and Raupach, M. R.: Correspondence: Rapid growth in $\mathrm{CO}_{2}$ emissions after the 2008-2009 global financial crisis, Nature Climate Change, 2, 2-4, 2012b.

Peters, G. P., Andrew, R. M., Boden, T., Canadell, J. G., Ciais, P., Le Quéré, C., Marland, G., Raupach, M. R., and Wilson, C.: The challenge to keep global warming below $2{ }^{\circ} \mathrm{C}$, Nature Climate Change, 3, 4-6, 2013.

Pfeil, B., Olsen, A., Bakker, D. C. E., Hankin, S., Koyuk, H., Kozyr, A., Malczyk, J., Manke, A., Metzl, N., Sabine, C. L., Akl, J., Alin, S. R., Bates, N., Bellerby, R. G. J., Borges, A., Boutin, J., Brown, P. J., Cai, W.-J., Chavez, F. P., Chen, A., Cosca, C., Fassbender, A. J., Feely, R. A., González-Dávila, M., Goyet, C., Hales, B., Hardman-Mountford, N., Heinze, C., Hood, M., Hoppema, M., Hunt, C. W., Hydes, D., Ishii, M., Johannessen, T., Jones, S. D., Key, R. M., Körtzinger, A., Landschützer, P., Lauvset, S. K., Lefèvre, N., Lenton, A., Lourantou, A., Merlivat, L., Midorikawa, T., Mintrop, L., Miyazaki, C., Murata, A., Nakadate, A., Nakano, Y., Nakaoka, S., Nojiri, Y., Omar, A. M., Padin, X. A., Park, G.-H., Paterson, K., Perez, F. F., Pierrot, D., Poisson, A., Ríos, A. F., Santana-Casiano, J. M., Salisbury, J., Sarma, V. V. S. S., Schlitzer, R., Schneider, B., Schuster, U., Sieger, R., Skjelvan, I., Steinhoff, T., Suzuki, T., Takahashi, T., Tedesco, K., Telszewski, M., Thomas, H., Tilbrook, B., Tjiputra, J., Vandemark, D., Veness, T., Wanninkhof, R., Watson, A. J., Weiss, R., Wong, C. S., and Yoshikawa-Inoue, H.: A uniform, quality controlled Surface Ocean $\mathrm{CO}_{2}$ Atlas (SOCAT), Earth Syst. Sci. Data, 5, 125-143, doi:10.5194/essd-5-125-2013, 2013.

Pongratz, J., Reick, C. H., Raddatz, T., and Claussen, M.: Effects of anthropogenic land cover change on the carbon cycle of the last millennium, Global Biogeochem. Cy., 23, GB4001, doi:10.1029/2009GB003488, 2009.

Pongratz, J., Reick , C. H., Houghton, R. A., and House, J. I.: Terminology as a key uncertainty in net land use flux estimates, Earth System Dynamics, 5, 177-195, 2013

Prather, M. J., Holmes, C. D., and Hsu, J.: Reactive greenhouse gas scenarios: Systematic exploration of uncertainties and the role of atmospheric chemistry, Geophys. Res. Lett., 39, L09803, doi:10.1029/2012GL051440, 2012.

Prentice, I. C., Farquhar, G. D., Fasham, M. J. R., Goulden, M. L., Heimann, M., Jaramillo, V. J., Kheshgi, H. S., Le Quéré, C., Scholes, R. J., and Wallace, D. W. R.: The Carbon Cycle and Atmospheric Carbon Dioxide, in: Climate Change 2001: The Scientific Basis. Contribution of Working Group I to the Third Assessment Report of the Intergovernmental Panel on Climate Change, edited by: Houghton, J. T., Ding, Y., Griggs, D. J., Noguer, M., van der Linden, P. J., Dai, X., Maskell, K., and Johnson, C. A., Cambridge University Press, Cambridge, United Kingdom and New York, NY, USA, 2001.

Raupach, M. R., Marland, G., Ciais, P., Le Quéré, C., Canadell, J. G., Klepper, G., and Field, C. B.: Global and regional drivers of accelerating $\mathrm{CO}_{2}$ emissions, P. Natl. Acad. Sci. USA, 104 10288-10293, 2007.

Regnier, P., Friedlingstein, P., Ciais, P., Mackenzie, F. T., Gruber, N., Janssens, I. A., Laruelle, G. G., Lauerwald, R., Luyssaert, S., Andersson, A. J., Arndt, S., Arnosti, C., Borges, A. V., Dale, A. W., Gallego-Sala, A., Goddéris, Y., Goossens, N., Hartmann, J., Heinze, C., Ilyina, T., Joos, F., La Rowe, D. E., Leifeld, J., Meysman, F. J. R., Munhoven, G., Raymond, P. A., Spahni, R., Suntharalingam, P., and Thullner M.: Anthropogenic perturbation of the carbon fluxes from land to ocean, Nat. Geosci., 6, 597-607, 2013.

Rhein, M., Rintoul, S. R., Aoki, S., Campos, E., Chambers, D., Feely, R. A., Gulev, S., Johnson, G. C., Josey, S. A., Kostianoy, A., Mauritzen, C., Roemmich, D., Talley, L. D., and Wang, F.: Chapter 3: Observations: Ocean, in: Climate Change 2013 The Physical Science Basis, Cambridge University Press, 2013.

Rödenbeck, C., Bakker, D. C. E., Metzl, N., Olsen, A., Sabine, C., Cassar, N., Reum, F., Keeling, R. F., and Heimann, M.: Interannual sea-air $\mathrm{CO}_{2}$ flux variability from an observation-driven ocean mixed-layer scheme, Biogeosciences Discuss., 11, 3167 3207, doi:10.5194/bgd-11-3167-2014, 2014.

Rypdal, K., Paciomik, N., Eggleston, S., Goodwin, J., Irving, W., Penman, J., and Woodfield, M.: Chapter 1 Introduction to the 2006 Guidelines, in: 2006 IPCC Guidelines for National Greenhouse Gas Inventories, edited by: Eggleston, S., Buendia, L., Miwa, K., Ngara, T., and Tanabe, K., Institute for Global Environmental Strategies (IGES), Hayama, Kanagawa, Japan, 2006.

Schimel, D., Alves, D., Enting, I., Heimann, M., Joos, F., Raynaud, D., Wigley, T., Prater, M., Derwent, R., Ehhalt, D., Fraser, P., Sanhueza, E., Zhou, X., Jonas, P., Charlson, R., Rodhe, H., Sadasivan, S., Shine, K. P., Fouquart, Y., Ramaswamy, V., Solomon, S., Srinivasan, J., Albritton, D., Derwent, R., Isaksen, I., Lal, M., and Wuebbles, D.: Radiative Forcing of Climate Change, in: Climate Change 1995 The Science of Climate Change. Contribution of Working Group I to the Second Assessment Report of the Intergovernmental Panel on Climate Change, edited by: Houghton, J. T., Meira Rilho, L. G., Callander, B. A., Harris, N., Kattenberg, A., and Maskell, K., Cambridge University Press, Cambridge, United Kingdom and New York, NY, USA, 1995.

Scripps: http://keelingcurve.ucsd.edu/ (last access: 7 November 2013), 2013.

Shevliakova, E., Pacala, S., Malyshev, S., Hurtt, G., Milly, P., Caspersen, J., Sentman, L., Fisk, J., Wirth, C., and Crevoisier, C.: Carbon cycling under 300 years of land use change: Impor- 
tance of the secondary vegetation sink, Global Biogeochem. Cy., 23, GB2022, doi:10.1029/2007GB003176, 2009.

Sitch, S., Smith, B., Prentice, I. C., Arneth, A., Bondeau, A., Cramer, W., Kaplan, J. O., Levis, S., Lucht, W., Sykes, M. T., Thonicke, K., and Venevsky, S.: Evaluation of ecosystem dynamics, plant geography and terrestrial carbon cycling in the LPJ dynamic global vegetation model, Glob. Change Biol., 9, 161-185, 2003.

Smith, B., Prentice, I. C., and Sykes, M. T.: Representation of vegetation dynamics in the modelling of terrestiral ecosystems: comparing two contrasting approaches withing European climate space, Global Ecol. Biogeogr., 10, 621-637, doi:10.1046/j.1466822X.2001.t01-1-00256.x, 2001.

Stocker, B. D., Roth, R., Joos, F., Spahni, R., Steinacher, M., Zaehle, S., Bouwman, L., and Prentice, I. C.: Multiple greenhouse-gas feedbacks from the land biosphere under future climate change scenarios, Nature Climate Change, 3, 666-672, $2013 \mathrm{a}$.

Stocker, T., Qin, D., and Platner, G.-K.: Climate Change 2013 The Physical Science Basis, Cambridge University Press, 2013b.

Tans, P. and Keeling, R. F.: http://www.esrl.noaa.gov/gmd/ccgg/ trends/ and http://scrippsco2.ucsd.edu/ (last access for both: 7 October 2013), 2013.

Tjiputra, J. F., Roelandt, C., Bentsen, M., Lawrence, D. M., Lorentzen, T., Schwinger, J., Seland, Ø., and Heinze, C.: Evaluation of the carbon cycle components in the Norwegian Earth System Model (NorESM), Geosci. Model Dev., 6, 301-325, doi:10.5194/gmd-6-301-2013, 2013.

Tranvik, L. J., Downing, J. A., Cotner, J. B., Loiselle, S. A., Striegl, R. G., Ballatore, T. J., Dillon, P., Finlay, K., Fortino, K., Knoll, L. B., Kortelainen, P. L., Kutser, T., Larsen, S.,, Laurion, I., Leech, D. M., McCallister, S. L., McKnight, D. M., Melack, J. M., Overholt, E., Porter, J. A., Prairie, Y., Renwick, W. H., Roland, F., Sherman, B. S., Schindler, D. W., Sobek, S., Tremblay, A., Vanni, M. J., Verschoor, A. M., von Wachenfeldt, E., and Weyhenmeyera, G. A.: Lakes and reservoirs as regulators of carbon cycling and climate, Limnol. Oceanogr., 54, 2298-2314, 2009.

UN: http://unstats.un.org/unsd/energy/ (last access: August 2013), $2013 \mathrm{a}$.

UN: http://unstats.un.org/unsd/industry/default.asp (last access: August 2013), 2013b.

UN: http://unstats.un.org/unsd/snaama/Introduction.asp (last access: August 2013), 2013c.
US Geological Survey: Mineral Commodities Summaries, US Geological Survey, 2013.

van der Werf, G. R., Dempewolf, J., Trigg, S. N., Randerson, J. T., Kasibhatla, P., Giglio, L., Murdiyarso, D., Peters, W., Morton, D. C., Collatz, G. J., Dolman, A. J., and DeFries, R. S.: Climate regulation of fire emissions and deforestation in equatorial Asia, P. Natl. Acad. Sci. USA, 15, 20350-20355, 2008.

van der Werf, G. R., Randerson, J. T., Giglio, L., Collatz, G. J., Mu, M., Kasibhatla, P. S., Morton, D. C., DeFries, R. S., Jin, Y., and van Leeuwen, T. T.: Global fire emissions and the contribution of deforestation, savanna, forest, agricultural, and peat fires (19972009), Atmos. Chem. Phys., 10, 11707-11735, doi:10.5194/acp10-11707-2010, 2010.

van Minnen, J. G., Goldewijk, K. K., Stehfest, E., Eickhout, B., van Drecht, G., and Leemans, R.: The importance of three centuries of land-use change for the global and regional terrestrial carbon cycle, Clim. Change, 97, 123-144, 2009.

van Oss, H. G.: Cement, US Geological Survey, June, 2013.

Wanninkhof, R., Park, G. -H., Takahashi, T., Sweeney, C., Feely, R., Nojiri, Y., Gruber, N., Doney, S. C., McKinley, G. A., Lenton, A., Le Quéré, C., Heinze, C., Schwinger, J., Graven, H., and Khatiwala, S.: Global ocean carbon uptake: magnitude, variability and trends, Biogeosciences, 10, 1983-2000, doi:10.5194/bg10-1983-2013, 2013.

Watson, R. T., Rodhe, H., Oeschger, H., and Siegenthaler, U.: Greenhouse Gases and Aerosols, in: Climate Change: The IPCC Scientific Assessment. Intergovernmental Panel on Climate Change (IPCC), edited by: Houghton, J. T., Jenkins, G. J., and Ephraums, J. J., Cambridge University Press, Cambridge, 1990.

Zaehle, S. and Friend, A. D.: Carbon and nitrogen cycle dynamics in the O-CN land surface model: 1. Model description, site-scale evaluation, and sensitivity to parameter estimates, Global Biogeochem. Cy., 24, GB1005, doi:10.1029/2009GB003521, 2010.

Zaehle, S., Friend, A. D., Friedlingstein, P., Dentener, F., Peylin, P., and Schulz, M.: Carbon and nitrogen cycle dynamics in the O$\mathrm{CN}$ land surface model: 2 . Role of the nitrogen cycle in the historical terrestrial carbon balance, Global Biogeochem. Cy., 24, GB1006, doi:10.1029/2009GB003522, 2010.

Zaehle, S., Ciais, P., Friend, A. D., and Prieur, V.: Carbon benefits of anthropogenic reactive nitrogen offset by nitrous oxide emissions, Nat. Geosci., 4, 601-605, 2011. 